\title{
CARIBIC DOAS observations of nitrous acid and formaldehyde in a large convective cloud
}

\author{
K.-P. Heue ${ }^{1,2, *}$, H. Riede ${ }^{1}$, D. Walter ${ }^{1,2}$, C. A. M. Brenninkmeijer ${ }^{1}$, T. Wagner ${ }^{1}$, U. Frieß ${ }^{2}$, U. Platt ${ }^{2}$, A. Zahn ${ }^{3}$, \\ G. Stratmann ${ }^{4}$, and H. Ziereis ${ }^{4}$ \\ ${ }^{1}$ Max-Planck-Institut für Chemie (MPIC), Mainz, Germany \\ ${ }^{2}$ Institut für Umweltphysik (IUP), Universität Heidelberg, Heidelberg, Germany \\ ${ }^{3}$ Institut für Meteorologie und Klimaforschung (IMK), Karlsruhe, Germany \\ ${ }^{4}$ Deutsches Zentrum für Luft- und Raumfahrt (DLR), Institut für Physik der Atmosphäre, Weßling, Germany \\ *now at: Deutsches Zentrum für Luft- und Raumfahrt (DLR), Earth Observation Centre, Weßling, Germany
}

Correspondence to: K.-P. Heue (klaus-peter.heue@dlr.de)

Received: 12 August 2013 - Published in Atmos. Chem. Phys. Discuss.: 16 September 2013

Revised: 28 February 2014 - Accepted: 26 April 2014 - Published: 1 July 2014

\begin{abstract}
The chemistry in large thunderstorm clouds is influenced by local lightning- $\mathrm{NO}_{\mathrm{x}}$ production and uplift of boundary layer air. Under these circumstances trace gases like nitrous acid (HONO) or formaldehyde (HCHO) are expected to be formed or to reach the tropopause region. However, up to now only few observations of HONO at this altitude have been reported.

Here we report on a case study where enhancements in $\mathrm{HONO}, \mathrm{HCHO}$ and nitrogen oxides $\left(\mathrm{NO}_{\mathrm{x}}\right)$ were observed by the CARIBIC flying laboratory (Civil Aircraft for the Regular Investigation of the atmosphere Based on an Instrument Container). The event took place in a convective system over the Caribbean Sea in August 2011. Inside the cloud the light path reaches up to $100 \mathrm{~km}$. Therefore the DOAS instrument on CARIBIC was very sensitive to the tracers inside the cloud. Based on the enhanced slant column densities of $\mathrm{HONO}, \mathrm{HCHO}$ and $\mathrm{NO}_{2}$, average mixing ratios of 37,468 and $210 \mathrm{ppt}$, respectively, were calculated. These data represent averages for constant mixing ratios inside the cloud. However, a large dependency on the assumed profile is found; for HONO a mixing ratio of $160 \mathrm{ppt}$ is retrieved if the total amount is assumed to be situated in the uppermost $2 \mathrm{~km}$ of the cloud.

The NO in situ instrument measured peaks up to $5 \mathrm{ppb}$ NO inside the cloud; the background in the cloud was about $1.3 \mathrm{ppb}$, and hence clearly above the average outside the cloud $(\approx 150 \mathrm{ppt})$. The high variability and the fact that the enhancements were observed over a pristine marine area led
\end{abstract}

to the conclusion that, in all likelihood, the high NO concentrations were caused by lighting. This assumption is supported by the number of flashes that the World Wide Lightning Location Network (WWLLN) counted in this area before and during the overpass.

The chemical box model CAABA is used to estimate the NO and HCHO source strengths which are necessary to explain our measurements. For NO a source strength of $10 \times$ $10^{9}$ molec $\mathrm{cm}^{-2} \mathrm{~s}^{-1} \mathrm{~km}^{-1}$ is found, which corresponds to the lightning activity as observed by the World Wide Lightning Location network, and lightning emissions of $5 \times 10^{25} \mathrm{NO}$ molec flash $^{-1}\left(2.3-6.4 \times 10^{25}\right)$. The uncertainties are determined by a change of the input parameters in the box model, the cloud top height and the flash density. The emission rate per flash is scaled up to a global scale and 1.9 (1.42.5) $\operatorname{tg~N~a}^{-1}$ is estimated. The HCHO updraught is of the order of $120 \times 10^{9} \mathrm{molec}^{-2} \mathrm{~s}^{-1} \mathrm{~km}^{-1}$. Also isoprene and $\mathrm{CH}_{3} \mathrm{OOH}$ as possible $\mathrm{HCHO}$ sources are discussed.

\section{Introduction}

Nitrous acid (HONO) and especially its relevance for $\mathrm{OH}$ production and hence photochemistry has been studied for many years (Platt et al., 1980). Despite this, the observational data set of HONO is very limited due to its low abundance and the general difficulty to measure this elusive species. Most studies have dealt with the production of HONO on 
surfaces in the boundary layer, and airborne measurements are scarce. Here we report on the measurement of HONO by DOAS on a passenger aircraft while flying through a large cloud system where also formaldehyde was detected. Because very few such cases are known, and HONO-specific papers are rare, we will first introduce the reactions involved in its production. Also some of the main sources of upper tropospheric formaldehyde are briefly summarized.

Nitrous acid accumulates during the night and initializes the photo-oxidation processes when photolysed just after sunrise. Its three main sources are direct emissions, chemical formation on surfaces and production in the gas phase. Its main sinks are photolysis and the reaction with $\mathrm{OH}$ :

$2 \mathrm{NO}_{2}+\mathrm{H}_{2} \mathrm{O} \stackrel{\text { surface }}{\rightarrow} \mathrm{HONO}+\mathrm{HNO}_{3}$

$\mathrm{NO}+\mathrm{OH} \stackrel{M}{\rightarrow} \mathrm{HONO}$

$\mathrm{HONO} \stackrel{h v}{\rightarrow} \mathrm{OH}+\mathrm{NO}(\lambda<400 \mathrm{~nm})$

$\mathrm{HONO}+\mathrm{OH} \rightarrow \mathrm{NO}_{2}+\mathrm{H}_{2} \mathrm{O}$.

The reactions (R2) and (R3) involve HONO as an intermediate storage of $\mathrm{OH}$. They lead to a photo-stationary state with neither destruction nor formation of $\mathrm{OH}$, which is slightly changed, when reaction (R4) is included. The $\mathrm{OH}$ radical is, however, definitely removed by the reaction with $\mathrm{NO}_{2}$

$\mathrm{OH}+\mathrm{NO}_{2} \stackrel{M}{\rightarrow} \mathrm{HNO}_{3}$

because photolysis of $\mathrm{HNO}_{3}$, which would reproduce $\mathrm{OH}$, is too slow to compete with wash out.

The overall fate of $\mathrm{OH}$ therefore depends on the ratio of $\mathrm{NO}$ (recycling) to $\mathrm{NO}_{2}$ (wash out). The ratio $\mathrm{NO}$ over $\mathrm{NO}_{2}$ depends on the titration of $\mathrm{NO}$ by $\mathrm{O}_{3}$ and the photolysis frequency of $\mathrm{NO}_{2}$ :

$\mathrm{NO}+\mathrm{O}_{3} \rightarrow \mathrm{NO}_{2}+\mathrm{O}_{2}$

$\mathrm{NO}_{2} \stackrel{h v}{\rightarrow} \mathrm{NO}+\mathrm{O}$

$\mathrm{O}+\mathrm{O}_{2} \stackrel{M}{\rightarrow} \mathrm{O}_{3}$

These reactions lead to the photo-stationary Leighton ratio

$L=\frac{\mathrm{NO}}{\mathrm{NO}_{2}}=\frac{J_{\mathrm{R} 7}}{\mathrm{O}_{3} \cdot k_{\mathrm{R} 6}}$.
The reaction constant $k_{\mathrm{R} 6}$ as well as any other reaction constants used in the following were taken from Atkinson et al. $(2004,2006)$. The temperature dependence was considered and unless stated differently, a temperature of $-50{ }^{\circ} \mathrm{C}$ was used. The photolysis frequencies were based on a simulated actinic flux, the absorption cross section (Table 1) and the quantum yields taken from Atkinson et al. (2004, 2006). We used a modelled actinic flux from the Tropospheric Ultraviolet and Visible (TUV) Radiation Model (quick TUV calculator http://cprm.acd. ucar.edu/Models/TUV/Interactive_TUV/, March 2013). To mimic the brightness of the cloud, a surface albedo of 1 was assumed. An ozone column of $250 \mathrm{DU}$ was included, based on SCIAMACHY data (www.iup.uni-bremen. de/scia-arc/, March 2013). Compared to a clear sky scenario $\left(\mathrm{j}_{\mathrm{NO}_{2}}=0.0127\right)$ with a ground albedo of $5 \%$ the actinic flux is roughly double $\left(\mathrm{j}_{\mathrm{NO}_{2}}=0.0253\right.$ ) (in the range of radiation enhancements in clouds given by Brasseur et al., 2002). For comparison, the intensity measured by the DOAS spectrographs in the cloud was two to three times as high as in the reference spectrum over the Atlantic ocean. In the boundary layer the Leighton ratio is typically less than 1; however, in the upper troposphere $\left(T=-50^{\circ} \mathrm{C}, p=205 \mathrm{hPa}\right.$, $\mathrm{O}_{3}=40 \mathrm{ppb}$ ) it can be as high as 10 , especially for the conditions we focus on in this paper. Furthermore, in cloud tops the solar radiation is enhanced by up to a factor of 3 (2-5 Brasseur et al., 2002) and therefore the photolysis frequency $J_{\mathrm{R} 7}$ increases and the Leighton ratio reaches up to 30 . Under these conditions $\mathrm{OH}$ radicals have a low probability of being removed, which leads to a large HONO formation rate on top of high-reaching thunderstorm clouds.

In thunderstorm clouds NO peak values up to $7 \mathrm{ppb}$ were found (Huntrieser et al., 2009). Simulations by Bhetanabhotla et al. (1985) predicted a lightning HONO to NO emission ratio of $6.7 \times 10^{-3}$. The product of the simulated HONO to NO ratio and the measured NO peak values results in initial peak values of $47 \mathrm{ppt}$ HONO caused by lightning. However, Dix et al. (2009) found higher values (70 ppt) averaged over a long light path in a polluted updraught.

Despite the expected high formation rate in cloud tops, airborne HONO measurements are scarce. Zhang et al. (2009) performed measurements in the boundary layer and above up to $2600 \mathrm{~m}$. They mainly confirmed the previous profile studies at towers, namely that there is a strong decrease in the HONO mixing ratio with height. Up to $74 \mathrm{ppt}$ were measured in the boundary layer and a range of 4 to $17 \mathrm{ppt}$ above. They concluded that the main sources for HONO are close to the ground. Jurkat et al. (2011) measured HONO at cruise altitude in aeroplane plumes to estimate air traffic HONO formation, and found up to $1.2 \mathrm{ppb}$ HONO and $65 \mathrm{ppb}$ NO. Dix et al. (2009), also using the DOAS instrument on the CARIBIC platform, found $70 \mathrm{ppt}$ of $\mathrm{HONO}, 280 \mathrm{ppt} \mathrm{NO}_{2}$, and $550 \mathrm{ppt} \mathrm{HCHO}$ over central China $\left(106.5^{\circ} \mathrm{E}, 27.1^{\circ} \mathrm{N}\right)$ in August 2006. In the vicinity of the cloud $\mathrm{NO}, \mathrm{NO}_{\mathrm{y}}, \mathrm{CO}$ and $\mathrm{O}_{3}$ were also enhanced, which indicates that a strong 
updraught of polluted boundary layer air had occurred. More details of this event are given in Dix (2007).

More information is available for formaldehyde in the upper troposphere. Under background conditions between 40 ppt (over the Pacific, Fried et al., 2003) and 200 ppt (over Europe, Stickler et al., 2006) are observed. The main HCHO source in the remote atmosphere is methane oxidation; the destruction is mainly by photolysis and reaction with $\mathrm{OH}$. Next to methane, methyl hydroperoxide $\left(\mathrm{CH}_{3} \mathrm{OOH}\right)$, isoprene and acetone are additional important precursors. The formaldehyde yield of the isoprene reaction with $\mathrm{OH}$ is $50 \%$ and about $40 \%$ for the reaction with $\mathrm{O}_{3}$ (Carter and Atkinson, 1996). The photolysis of acetone results in $\mathrm{CH}_{3} \mathrm{CO}$ and $\mathrm{CH}_{3}$, which with subsequent reactions yields formaldehyde. Several sensitivity studies showed a strong positive correlation between $\mathrm{HCHO}$ concentration and $\mathrm{NO}_{\mathrm{x}}$ (Stickler et al., 2006, and references therein).

The CARIBIC (Civil Aircraft for the Regular Investigation of the atmosphere Based on an Instrument Container) flying laboratory measures once per month the chemical composition at cruise altitude $(10-12 \mathrm{~km})$ during four consecutive Lufthansa flights. In this study we present CARIBIC DOAS observations of $\mathrm{HONO}, \mathrm{NO}_{2}$ and $\mathrm{HCHO}$ inside a large cloud system of about $480 \mathrm{~km}$ length over the Caribbean islands of Guadeloupe. To our knowledge, this is only the second publication about nitrous acid in a deep convective cloud, after Dix et al. (2009). Whereas Dix et al. (2009) (also using CARIBIC) detected HONO in a cloud system over China under polluted conditions, here we deal with uplifted clean oceanic air. The islands of Guadeloupe (France) have about 0.4 million inhabitants and no significant industry (www.wikipedia.org, May 2013). Therefore the local pollution levels can be expected to be low.

Nitrous acid was also detected on other occasions with the CARIBIC DOAS instrument, in particular when the aeroplane flew over clouds. In most cases the HONO slant column densities (SCDs) are close to the detection limit (1$2 \times 10^{15}$ molec $\mathrm{cm}^{-2}$ ). Due to the shielding effect of the cloud the $\mathrm{O}_{4} \mathrm{SCD}$ are low in all these cases. On the other hand, there are cases where comparable low $\mathrm{O}_{4}$ SCDs are observed but no increase in HONO is found. The oxygen dimer $\mathrm{O}_{4}$ is often used to estimate the length of the light path in DOAS measurements. The absorption is proportional to the square of the $\mathrm{O}_{2}$ concentration. Therefore, the observed changes in the absorption are caused by changes in the light path, and do not result from changes in the concentration. Between July 2011 and June 2013 about 100 cases were observed where the $\mathrm{O}_{4} \mathrm{SCD}$ was significantly reduced, and HONO was detected in 50 cases. Due to the high column densities inside the cloud, and the enhancement in $\mathrm{HCHO}$ and $\mathrm{NO}_{\mathrm{x}}$ we will focus on this special event here.

\section{The CARIBIC instruments and the CAABA box model}

The CARIBIC instrument container is installed on a Lufthansa Airbus A340-600 retrofitted with a three-probe (trace gases, water and aerosol) inlet system. The aeroplane carries the instrument container on a monthly basis during four consecutive regular passenger flights for 2-3 days. $\mathrm{CO}, \mathrm{CO}_{2}, \mathrm{O}_{3}, \mathrm{NO}, \mathrm{NO}_{2}, \mathrm{NO}_{\mathrm{y}}$ (Sect. 2.2), $\mathrm{CH}_{4}$, some organic compounds (e.g. acetone), mercury, total and gaseous water (Sect. 2.1) are measured in real time. Aerosols are measured for diameters larger than 4,12 and $18 \mathrm{~nm}$ with $3 \mathrm{CPCs}$ (condensation particle counters) and from $117 \mathrm{~nm}$ to $1.3 \mu \mathrm{m}$ with an OPC (optical particle counter). In addition, 16 aerosol samples and 116 air samples are collected for post-flight laboratory analysis of aerosol elemental composition (Nguyen et al., 2006) and of a host of trace gases (Schuck et al., 2009; Baker et al., 2010). A DOAS instrument (Sect. 2.3) adds a remote sensing capacity to complete the instrumental package using three miniature DOAS telescopes mounted in the pylon. A video camera in the inlet pylon takes a frame every second for post-flight cloud cover analysis. The instruments are maintained and operated by nine scientific groups from research institutes in Europe (http://www.caribic-atmospheric.com, May 2013).

The trace gas and aerosol measurements are complemented by standard in-flight observations (e.g. position, temperature, wind speed, pressure) provided by the aeroplane's ARINC data bus system. The Royal Dutch Meteorological Institute (KNMI) supports the CARIBIC project with trajectory calculations along the flight track based on the TRAJKS model (Scheele et al., 1996; Stohl et al., 2001). Both forward and backward trajectories for 2 and 8 days respectively are calculated using ECMWF weather data interpolated to the position and time of the CARIBIC observation.

\subsection{Water measurements}

The CARIBIC container has two systems for water measurements (Brenninkmeijer et al., 2007). A chilled mirror frost point hygrometer (BUCK CR2) with a temporal resolution up to 3 min depending on the humidity, and a two-channel photo-acoustic laser spectrometer with a temporal resolution of $3 \mathrm{~s}$. The detection limit is $0.5 \mathrm{ppm}$ and the accuracy is $0.4 \mathrm{~K}$ for the frost point hydrometer. The sensitivity of the photo-acoustic sensor may vary by a few percent within an hour, therefore the instrument is post-flight calibrated by comparison with the frost point instrument. The inlet probe for water allows the measurement of total water (including cloud droplets) by using a forward-pointing inlet and gaseous water by a second sidewards orifice. The forward-facing inlet uses the ram pressure $(60-100 \mathrm{hPa})$ to transport the inlet air through inlet tubing to both instruments, frost point and photo-acoustic. The sidewards-facing inlet is connected to the photo-acoustic sensor only, and uses a diaphragm pump, 
installed downstream. This set-up allows the measurement of total water and gaseous water so that the difference between the two quantities gives the cloud water content.

\subsection{Nitrogen oxides measurements}

The NO-NO ${ }_{\mathrm{y}}$ instrument on CARIBIC uses a two-channel chemiluminescence detector (Ecophysics CLD-790 SR) to measure NO with a time resolution of $1 \mathrm{~s}$. Details on the instrument are given in Brenninkmeijer et al. (2007) and Ziereis et al. (2000). A catalytic conversion technique is used for $\mathrm{NO}_{\mathrm{y}}$ measurements. Using $\mathrm{H}_{2}$ as a reducing gas, $\mathrm{NO}_{\mathrm{y}}$ species are reduced to NO inside a heated gold tube. Nitrogen monoxide is subsequently measured using chemiluminescence. During the flight discussed here the $\mathrm{NO}_{\mathrm{y}}$ channel was switched off due to technical problems. In-flight the background signal is measured every $10 \mathrm{~min}$ for about $1 \mathrm{~min}$. The NO detectors are calibrated prior and after each flight sequence, i.e. twice per month. The uncertainty of the NO measurements is about $8 \%$ at $50 \mathrm{ppt} \mathrm{NO}$.

\subsection{DOAS on CARIBIC}

The CARIBIC DOAS instrument has been described in detail in Dix et al. (2009) and Walter et al. (2012). The following basic description is taken from Heue et al. (2010). The DOAS instrument measures scattered sunlight and uses differential optical absorption spectroscopy (DOAS) (Platt and Stutz, 2008) to retrieve trace gas amounts in the atmosphere. The retrieved SCD is the absorber concentration integrated along the light path.

The SCD highly depends on the light path in the atmosphere. When measuring in or through clouds the light paths might be enhanced due to the scattering events on the cloud droplets. To estimate the length and the distribution of the light paths, usually the measured $\mathrm{O}_{4} \mathrm{SCDs}$ are compared to model simulations. We used the 3-D Monte Carlo radiative transfer model "McArtim" (Deutschmann et al., 2011) to estimate the cloud's extinction profile. Details on the properties of the simulated cloud are described in Sect. 3.1 and in Appendix A.

The CARIBIC DOAS instrument observes scattered sunlight under three different elevation angles $(-82,-10$ and $+10^{\circ}$ relative to the horizon). Three small telescopes present in the CARIBIC pylon are connected to three spectrometers mounted in the container via quartz fibre bundles. The wavelength ranges of all spectrometers cover the interval from 300 to $400 \mathrm{~nm}$ with a spectral resolution of $0.5 \mathrm{~nm}$ (full width at half maximum). The time resolution is $8 \mathrm{~s}$, which corresponds to $2 \mathrm{~km}$ horizontal resolution.

A fitting window from 328 to $378 \mathrm{~mm}$ (four HONO absorption bands and four HCHO absorption bands) was used to retrieve the slant column densities. A list of the included absorption cross sections including the Ring effect is given in Table 1 . In a second fitting window $(322-378 \mathrm{~nm})$ an-
Table 1. Cross sections used in the DOAS retrieval.

\begin{tabular}{ll}
\hline Reference spectrum & Reference \\
\hline $\mathrm{NO}_{2}$ & Vandaele et al. (1996) \\
$\mathrm{HCHO}$ & Meller and Moortgat (2000) \\
$\mathrm{HONO}$ & Stutz et al. (2000) \\
$\mathrm{O}_{4}$ & http://spectrolab.aeronomie.be/o2.htm \\
$\mathrm{O}_{3}$ & Bogumil et al. (2003) (223 K and 243 K) \\
$\mathrm{BrO}$ & Wilmouth et al. (1999) (228 K) \\
$\mathrm{Ring}$ & Bussemer (1993) \\
Ring2 & Wagner et al. (2009a) (Ring. $\left.\lambda^{4}\right)$ \\
\hline
\end{tabular}

other HCHO absorption band is included. The data are used for comparison. The spectral structures of the absorbers are clearly identified in both fitting windows, and the retrieved column densities agree well within the errors (Fig. 1).

For some co-added spectra (10 spectra co-added) we also tested the sensitivity of the SCD on the wavelength range between 320.9 and $353.3 \mathrm{~nm}$ for the lower end of the fitting window and from 360.9 to 395.0 for the upper end. Details on this method of the "retrieval wavelength fitting" can be found in Vogel et al. (2013). The fitting window had a minimum range of 300 channels and a maximum of 900 channels. The HONO SCD for the nadir spectrum (18:26:1618:27:40 UTC) varied between $4.7 \times 10^{15} \mathrm{molec} \mathrm{cm}^{-2}$ for the wavelength range $339.2-367.7 \mathrm{~nm}$ ( 2 HONO absorption bands) and $1.7 \times 10^{15} \mathrm{molec} \mathrm{cm}^{-2}$ for 345.6 to $369 \mathrm{~nm} \mathrm{(1}$ HONO absorption band). In total 8379 wavelength intervals were considered, resulting in a mean SCD of $3.16 \pm 0.57 \times$ $10^{15} \mathrm{molec} \mathrm{cm}^{-2}$. For the same spectrum the mean BrO SCD was $6.8 \pm 6.2 \times 10^{13} \mathrm{molec}^{-2}$, which demonstrates that the $\mathrm{BrO}$ absorption cross section cannot be identified in this spectrum, because the SCD was below the detection limit.

In Table 2 the typical fit errors inside the cloud are given for the $8 \mathrm{~s}$ spectra. For HONO this error agrees well with the variation observed in the retrieval wavelength fit, for $\mathrm{BrO}$ it is underestimated. When 10 spectra are added the error is reduced by a factor of $\approx 3$. For unknown reasons the light intensity in the $-10^{\circ}$ spectrograph was lower. As a consequence of that, the fit error is higher here compared to the other two spectrometers.

\subsection{CAABA box model}

CAABA (Chemistry As A Boxmodel Application) provides a flexible atmospheric chemistry box modelling framework (Sander et al., 2011). It features a modular structure in which processes (e.g. emission and sedimentation) and simulation modes (e.g. Lagrangian simulations along trajectories) can be easily switched on and off independently. For the present study, the steady-state simulation mode was chosen, in which defined longer-lived chemical species are kept at fixed mixing ratios, while shorter-lived species adapt and equilibrate to the given boundary conditions, including temperature, 

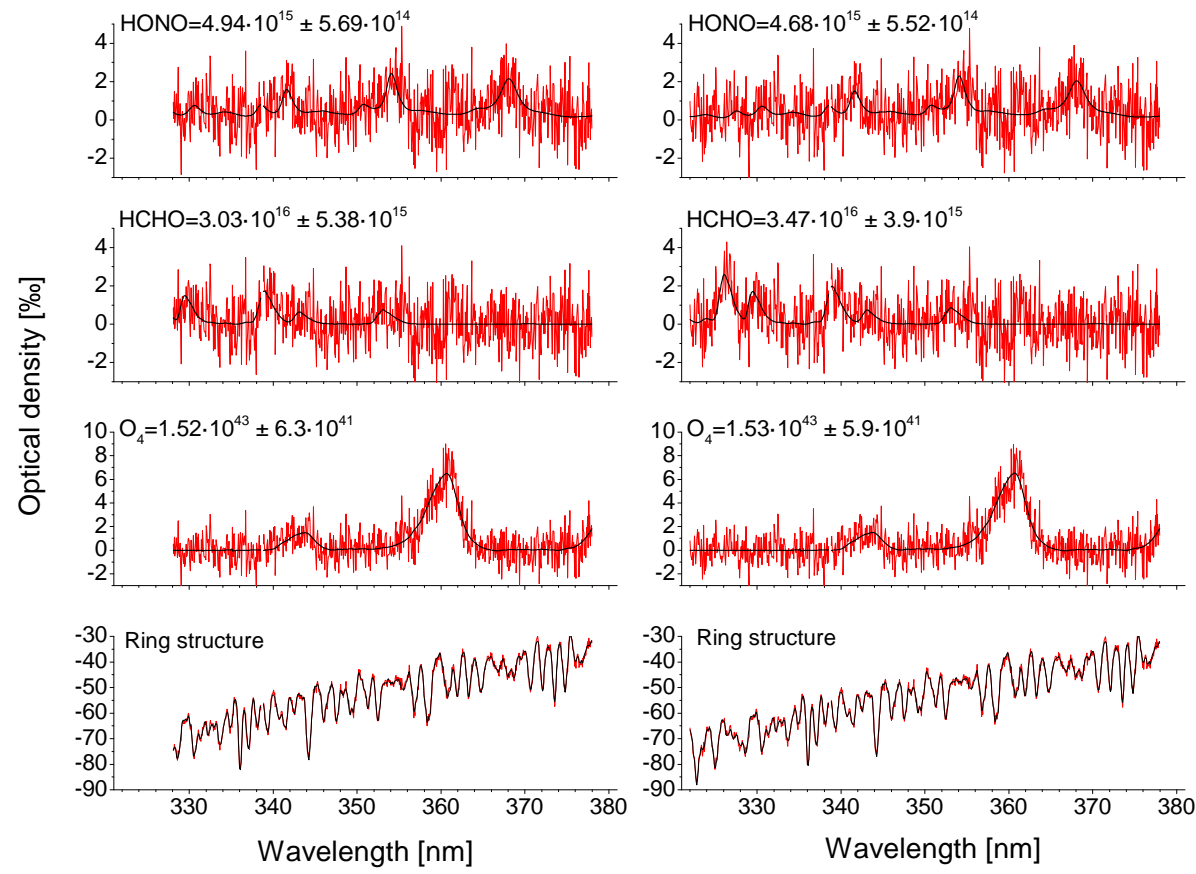

Figure 1. Example fits using two different wavelength ranges for spectrum C0004375 (18:27:04 UTC inside the cloud) of the nadir spectrometer. For each absorber the slant column density is given next to the name. As the fit coefficient of the ring spectrum is irrelevant for the rest of the paper it is omitted here. Left: the standard fitting window is used $(328-378 \mathrm{~nm})$; right: an extended range beginning at $322 \mathrm{~nm}$ is shown to include another $\mathrm{HCHO}$ absorption band. Within the error margins the results of both fits agree quite well.

Table 2. Typical fit errors for slant column densities inside the cloud. Because the intensity in the $-10^{\circ}$ spectrograph was lower the typical fit errors are higher compared to the other two spectrographs. The $\mathrm{BrO}$ fit error is included here to estimate the detection limit for bromine monoxide inside the cloud.

\begin{tabular}{rrrrrr}
\hline & $\begin{array}{r}\mathrm{NO}_{2} \\
{\left[10^{15}\right]}\end{array}$ & $\begin{array}{r}\mathrm{HCHO} \\
{\left[10^{15}\right]} \\
\text { molec cm }\end{array}$ & $\begin{array}{r}\mathrm{HONO} \\
{\left[10^{14}\right]}\end{array}$ & $\begin{array}{r}\mathrm{BrO} \\
{\left[10^{13}\right]}\end{array}$ & $\begin{array}{r}\mathrm{O}_{4} \\
{\left[10^{41}\right]}\end{array}$ \\
$\mathrm{molec}^{2} \mathrm{~cm}^{-5}$
\end{tabular}

humidity, pressure, solar zenith angle, and resulting reaction rates.

The atmospheric-chemistry reaction mechanism provided by the chemistry module MECCA is easily adaptable by preprocessing before the actual simulation: certain species, reaction types, or entire atmospheric domains can be selected or excluded. For the standard setup in this study, tropospheric gas phase reactions were selected, comprising 448 species up to four $\mathrm{C}$ atoms, detailed isoprene chemistry, and 318 reactions of which 72 are photolytic. Halogen, sulphur, and mercury chemistry was excluded. As far as observations were available, they were included as input parameters to the model as detailed in Sect. 5.4.

\section{Observations}

During the flight to Caracas on 16 August 2011 the CARIBIC aeroplane flew through an extensive cloud system at $61.64^{\circ} \mathrm{W}, 16.19^{\circ} \mathrm{N}$ over the Caribbean islands of Guadeloupe. While $\mathrm{NO}_{\mathrm{x}}$ was enhanced, no enhancements in the typical pollution tracers $\mathrm{CO}, \mathrm{CO}_{2}$, ethane or propane were measured (only $\mathrm{CO}$ is shown in Fig. 2). This is consistent with the ECMWF 5-day back-trajectories originating from the marine boundary layer of the central tropical Atlantic ocean.

Also, 15 min before or after the intersection of the cloud, none of these tracers were enhanced, including NO, which was measured at typical background levels of 100-300 ppt. Ozone mostly showed an enhanced variability $( \pm 5 \mathrm{ppb})$, which might be caused by an instrumental issue, and a slight decrease compared to the background level of 30-40 ppb. The last whole air sample of this flight (No. 14) was collected while leaving the cloud (18:31:02 UTC). In the laboratory analysis, no enhancements in ethane, propane, butane or methyl chloride were found. Instead, compared to the preceding samples most mixing ratios were reduced $(\mathrm{Ta}-$ ble 3). The two previous samples are not representative of the background conditions, as the trajectories originate from above the US coast. Because inside the cloud scavenging efficiently removes large particles (Ekman et al., 2006), the strong increase in the large aerosols (diameter between 117 


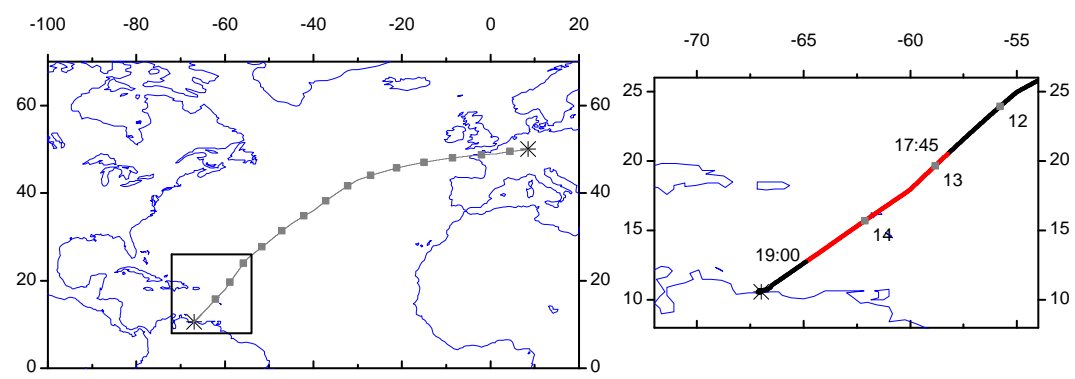

Flight No 353 Frankfurt to Caracas 16 August 2011

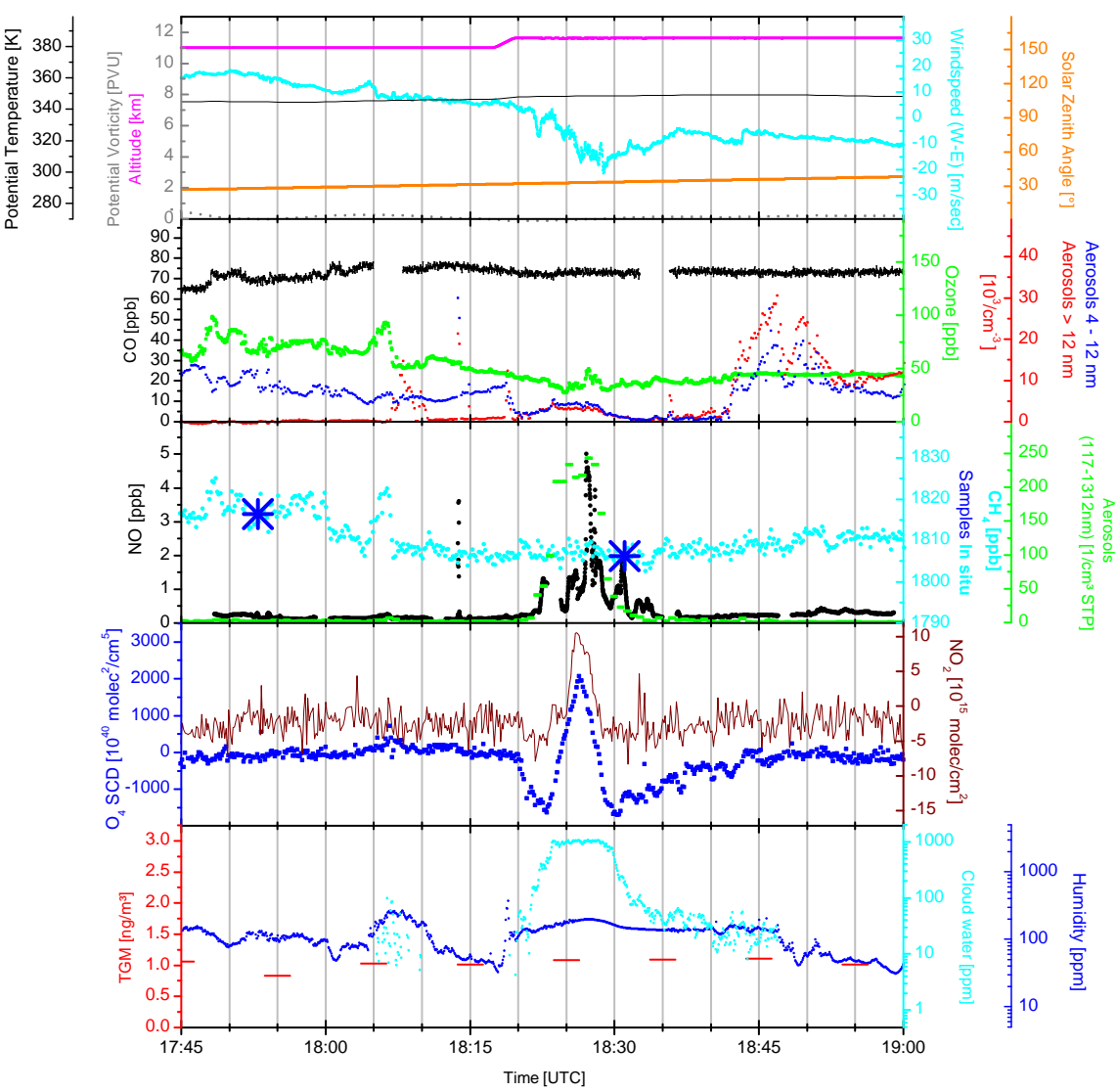

Figure 2. Overview of selected CARIBIC measurements around the cloud (18:25 UTC). On top a map with the complete flight is shown. The box illustrates the area of the zoomed map, where the part of the flight track between 17:45 and 19:00 UTC (Table 3) is shown in red and the positions of the last three air samples $(12,13,14)$ are shown. The cloud is recorded by the cloud water data (lowermost panel). Concomitant NO and DOAS data show some interesting features. The strong variability of NO might be attributed to lightning activity in the cloud system. The DOAS $\left(\mathrm{O}_{4}\right.$ and $\left.\mathrm{NO}_{2}\right)$ data shown here, come from the nadir channel.

and $1312 \mathrm{~nm}$ ) is unexpected. It is, however, known that the break-up of ice crystals, as can happen on the rim of the aerosol inlet shroud, leads to an increase in particles (Baumgardner et al., 2011).

The DOAS data showed a strong increase in $\mathrm{O}_{4}$, which indicates a long light path inside the cloud. Moreover, the slant column densities for $\mathrm{NO}_{2}, \mathrm{HCHO}$ and $\mathrm{HONO}$ were enhanced. The $\mathrm{O}_{4}$ time series in $-10^{\circ}$ and in nadir show a strong decrease between 18:17 and 18:49 UTC (Fig. 3). On top of this reduction there is an even stronger increase at
18:25 UTC. A similar time series is found for $+10^{\circ}$, however the decrease is much smaller. The reduction in the $\mathrm{O}_{4}$ column densities for both downward-looking telescopes can be explained by a shielding effect of the cloud just below the aeroplane. Most of the detected light is reflected at the bright cloud by which the lower part of the atmosphere containing high $\mathrm{O}_{4}$ concentrations is shielded.

The strong increase is observed when the aeroplane is inside the cloud and is mainly caused by multiple scattering. Although the largest fraction of the observed light was 
Table 3. Overview of several CARIBIC in situ measurements inside (18:24:00-18:29:29 UTC) and outside (18:50-19:00 UTC) the cloud. Because the distribution of the NO values inside the cloud is far from Gaussian, we used the first, second and third quartile instead of the average and the standard deviation. The NO background values were measured before entering the cloud, because for the period after the cloud there seems to be an enhancement due to lightning $\mathrm{NO}_{\mathrm{x}}$ advection. Air sample No. 14 was taken at 18:31:02 UTC, which was close to the cloud edge. For comparison, the values of the two previous samples (No. 12 at 17:14:57 UTC and No. 13 at 17:52:57 UTC) are listed, as no sample was taken during the background period. Therefore, the in situ methane measurements cannot be expected to agree with the samples. Finally, the DOAS slant column densities used for further analysis are included. Here the data close to the maximum were averaged.

\begin{tabular}{|c|c|c|c|c|c|c|}
\hline Trace gas & & \multicolumn{2}{|c|}{$\begin{array}{l}\text { Background } \\
18: 50-19: 00\end{array}$} & \multicolumn{3}{|c|}{$\begin{array}{r}\text { Inside the cloud } \\
\text { 18:24:00-18:29:29 }\end{array}$} \\
\hline NO [ppt] & & \multicolumn{2}{|c|}{$150 \pm 42$} & \multicolumn{3}{|c|}{$1250,770-1680$} \\
\hline $\mathrm{O}_{3}[\mathrm{ppb}]$ & & \multicolumn{2}{|c|}{$44 \pm 0.5$} & \multicolumn{3}{|c|}{$35 \pm 5$} \\
\hline $\mathrm{CO}[\mathrm{ppb}]$ & & \multicolumn{2}{|c|}{$73 \pm 0.9$} & \multicolumn{3}{|c|}{$73 \pm 0.9$} \\
\hline $\mathrm{CO}_{2}[\mathrm{ppb}]$ & & \multicolumn{2}{|c|}{$391.8 \pm 7.2$} & \multicolumn{3}{|c|}{$395.3 \pm 6$} \\
\hline Methane [ppb] & & \multicolumn{2}{|c|}{$1810 \pm 1.3$} & \multicolumn{3}{|c|}{$1807 \pm 1.5$} \\
\hline Acetone [ppt] & & \multicolumn{2}{|c|}{$300 \pm 100$} & \multicolumn{3}{|c|}{$300 \pm 100$} \\
\hline Methanol [ppt] & & \multicolumn{2}{|c|}{$1058 \pm 245$} & \multicolumn{3}{|c|}{$950 \pm 213$} \\
\hline Samples & No. 12 & & No. 13 & & & No. 14 \\
\hline Methane [ppb] & 1814 & & 1816 & & & 1806 \\
\hline Ethane [ppt] & 653.6 & & 790 & & & 400 \\
\hline Propane [ppt] & 44.9 & & 87.7 & & & 10.7 \\
\hline$n$-Butane [ppt] & 2.07 & & 5.06 & & & 1.85 \\
\hline Methyl chloride [ppt] & 645.7 & & 642.7 & & & 604.1 \\
\hline \multicolumn{2}{|l|}{ DOAS } & \multicolumn{2}{|c|}{ Background } & \multicolumn{3}{|c|}{ Inside the cloud } \\
\hline Viewing direction & $10^{\circ}$ & $-10^{\circ}$ & $-82^{\circ}$ & $10^{\circ}$ & $-10^{\circ}$ & $-82^{\circ}$ \\
\hline $\mathrm{HONO}\left[10^{15}\right.$ molec $\left.\mathrm{cm}^{-2}\right]$ & 0.9 & 2.2 & 2 & 3.5 & 5 & 5 \\
\hline $\mathrm{HCHO}\left[10^{16}\right.$ molec $\left.\mathrm{cm}^{-2}\right]$ & 0.6 & -0.2 & 0.2 & 3.6 & 2.3 & 3.2 \\
\hline $\mathrm{NO}_{2}\left[10^{15}\right.$ molec cm $\left.\mathrm{cm}^{-2}\right]$ & -3 & -5 & -2 & 10.5 & 8 & 10.5 \\
\hline $\mathrm{O}_{4}\left[10^{40} \mathrm{molec}^{2} \mathrm{~cm}^{-5}\right]$ & 0 & 0 & 0 & 2500 & 700 & 2000 \\
\hline
\end{tabular}

probably scattered close to the flight altitude, the lower altitude levels also contribute to the $\mathrm{O}_{4}$ signal (see Appendix A). The pictures taken by the video camera confirm the first interpretation of the $\mathrm{O}_{4}$ SCDs. A sketch of the cloud including the CARIBIC flight track above the cloud and through a part of it, is shown in Fig. 4. The time series of the intensities showed a strong increase at the time when the $\mathrm{O}_{4}$ is reduced and remains enhanced until leaving the cloud at 18:49 UTC. Hence no significant change is observed inside the cloud.

It is interesting to note that the HONO SCD in nadir and $-10^{\circ}$ increases and the $\mathrm{O}_{4}$ SCD decreases, while flying above the cloud. Later on, when the aeroplane is inside the cloud, both $\mathrm{O}_{4}$ and HONO reach their maximum SCDs. Therefore, we conclude that there is no spectroscopic interference between $\mathrm{HONO}$ and $\mathrm{O}_{4}$ which might have caused an artificial anti-correlation of these two slant column densities. Instead, an enhanced HONO concentration in the top layer of the cloud or above is indicated. Some other features in the HONO SCD time series outside the period of interest showed
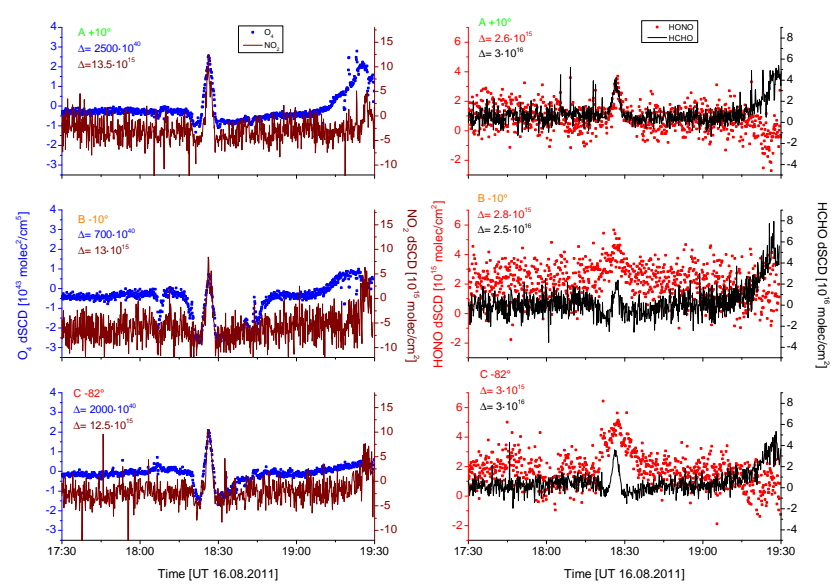

Figure 3. DOAS data for $\mathrm{O}_{4}, \mathrm{NO}_{2}, \mathrm{HONO}$ and $\mathrm{HCHO}$ (from left to right) for the three lines of sight, $+10^{\circ}$ (top), $-10^{\circ}$ (middle) and nadir (bottom). When flying through the cloud a strong increase in all these time series is observed. Especially for the downwardlooking telescopes the $\mathrm{O}_{4}$ column densities are reduced relative to the background, while the aeroplane flies over the cloud. The difference between the background level and the enhancement inside the cloud is given as $\triangle \mathrm{SCD}$ in the figures.

a wide scatter when varying the wavelength interval, and are therefore not considered as real. Also the background SCDs are not realistic because of the range of the scatter observed around the reference spectrum.

The differences in the SCDs for each species and each viewing direction are listed in Fig. 3 and Table 3. They are calculated as the difference between the background and the maximum enhancement inside the cloud. In Sect. 4 the retrieval of the mixing ratios is based on these values.

The horizontal expansion of the cloud can be estimated by multiplying the cruising velocity of the aeroplane ( 480 knots $\approx 248 \mathrm{~m} \mathrm{~s}^{-1}$ ) with the time span of the $\mathrm{O}_{4}$ anomaly in the time series. It took roughly $30 \mathrm{~min}$ to fly over the cloud system, implying that it was about $480 \mathrm{~km}$ wide. The enhancement in the DOAS $\mathrm{O}_{4} \mathrm{SCDs}$ was about $3 \mathrm{~min}$ long, whereas the maximum in the cloud water was observed for about 5 min (Fig. 2; 18:24:00-18:29:29 UTC). The difference might be explained by a shorter light path towards the edges of the clouds. We conclude that the part of the cloud crossed was about $50-80 \mathrm{~km}$ wide. During the flight towards the cloud, the video camera shot several pictures of the cloud. These pictures were used for a triangulation (Heue et al., $2011)$ to estimate the cloud base $(\approx 1 \mathrm{~km})$ and cloud top height $(\approx 9 \mathrm{~km})$ of the part the plane flew over. However, once the plane was above the cloud, no additional information on either of these quantities could be retrieved from the video signal. 


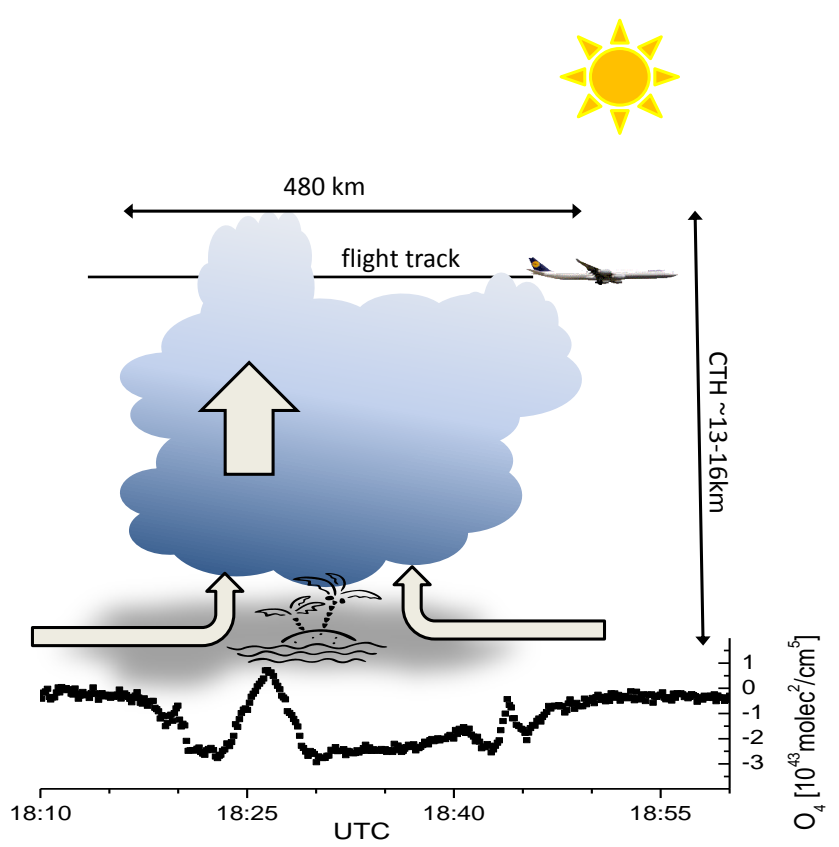

Figure 4. Sketch of the cloud system that the CARIBIC aeroplane flew over and passed through. The width of the total cloud as well as the small part the aeroplane passed through is estimated based on the time series of the $-10^{\circ} \mathrm{O}_{4} \mathrm{SCD}$, which is shown below the cloud. The rest of the sketch is arbitrary. The arrows indicate the air masses flowing into the cloud and upwards inside.

\subsection{Light path estimates}

Details on the radiative transfer simulations and the resulting light path estimates are given in Appendix A. Therefore only a brief summary will be given here. In the DOAS measurements (Fig. 3 and Table 3) strong enhancements in the $\mathrm{O}_{4} \mathrm{SCDs}$ can be seen. As mentioned in the Introduction, the comparison of measured and simulated $\mathrm{O}_{4}$ column densities are a common tool to estimate the length of the light path (e.g. Erle et al., 1995; Wagner et al., 2004; Frieß et al., 2006; Heue, 2005). Recent studies have shown that the measured SCDs of many scattered light measurements have to be corrected by a factor of 0.8 (e.g. Wagner et al., 2009b; Clémer et al., 2010). Because our measurements are not sufficient to constrain the correction factor, we apply the one used in the literature. The possible uncertainty caused by applying this correction factor is about $+10 \%$ for the mixing ratios (Sect. 4.1).

The measured $\mathrm{O}_{4}$ SCDs were compared with modelled data from the three-dimensional radiative transfer model McArtim (Deutschmann et al., 2011). We simulated several clouds keeping most dimensions fixed and varied the cloud extinction (CE) and the height of the uppermost part of the cloud $(\mathrm{CTH})$. The cloud base height $(1 \mathrm{~km})$ was estimated from the video data as well as the height of the part of the cloud the plane flew over $(9 \mathrm{~km})$. The model enabled us to simulate a 3-D cloud with a base area of $150 \times 60 \mathrm{~km}^{2}$ and on top of it a small cloud of $50 \times 20 \mathrm{~km}^{2}$. The dimensions were smaller than the real cloud to reduce computer time without being influenced by the cloud edge. The varied parameters (CE and CTH) could not be constrained based on direct CARIBIC observations. Therefore we tried to determine them with the $\mathrm{O}_{4}$ data. However, it seems that the information content was insufficient, because a whole range of possible solutions was found (Fig. A2). The minimum differences between modelled and simulated $\mathrm{O}_{4}$ data describe a curve ranging from a CTH of $16 \mathrm{~km}$ and a CE of $7.6 \mathrm{~km}^{-1}$ to $13.5 \mathrm{~km} \mathrm{CTH}$ and $20.2 \mathrm{~km}^{-1} \mathrm{CE}$ (Fig. A2). For this range the path length varied between 107 and $92 \mathrm{~km}$ (Table 4).

The same convective system was observed by the MODIS Aqua instrument (data available at: http://ladsweb.nascom. nasa.gov/, February 2013) at 17:20 UTC i.e. $1 \mathrm{~h}$ before the CARIBIC measurements. According to these data the cloud top pressure was between 120 and $105 \mathrm{hPa}$ and the cloud top temperature between 197.5 and $200 \mathrm{~K}$, which corresponds to a CTH of 15 to $16 \mathrm{~km}$. This is comparable to our retrieved altitude range, but in the $1 \mathrm{~h}$ period between the MODIS observation and the CARIBIC flight, the cloud may have changed. A more detailed comparison between MODIS and CARIBIC is described in the radiative transfer modelling, see Appendix A2.

\section{Trace gas concentrations in the cloud}

In contrast to the in situ $\mathrm{NO}$ and $\mathrm{H}_{2} \mathrm{O}$ measurements the DOAS observations are averaged over a long light path inside the cloud. Therefore for a comparison or a combined analysis we have to assume that these measurements are representative of the rest of the cloud. Nitrogen monoxide (Fig. 2; 18:24:00-18:29:29 UTC) had an average value of $1.48 \pm 1 \mathrm{ppb}$ (median 1.24 ppb) but showed several sharp peaks. Often such peaks are caused by air traffic (e.g. 18:13 UTC; Fig. 2) with a concurrent peak in the aerosol data. Inside the cloud also lightning can produce large amounts of $\mathrm{NO}_{\mathrm{x}}$ (e.g. Schumann and Huntrieser, 2007). In our case lightning is the most likely source of the NO peaks and the enhanced NO background as the peaks are broader than for contrails and not accompanied by a peak in the fine aerosols as often observed in contrails.

Although the DOAS observations average over a long light path $(\approx 90-100 \mathrm{~km}$, Table 4$)$, the instrument is most sensitive close to the flight altitude, where the local Box-AMF is close to 20 . This means that it is roughly three times higher than in the cloud-free case. Nevertheless, also lower parts of the cloud contribute to the signal, and are consequently considered in the light path estimate. To derive the mixing ratio of $\mathrm{HONO}, \mathrm{HCHO}$, and $\mathrm{NO}_{2}$, we again assume a constant mixing ratio (MR) inside the cloud, which can be derived from 
the measurements via

$$
\begin{aligned}
\mathrm{dSCD} & =\mathrm{SCD}_{\text {cloud }}-\mathrm{SCD}_{\text {ref }} \\
& =\sum_{i}\left(\mathrm{BoxAMF}_{i, \text { cloud }} \cdot \mathrm{VCD}_{i, \text { cloud }}\right) \\
& -\sum_{i}\left(\text { BoxAMF }_{i, \text { ref }} \cdot \mathrm{VCD}_{i, \text { ref }}\right) \\
& =\mathrm{MR} \cdot \sum_{i}\left(\mathrm{BoxAMF}_{i, \text { cloud }} \cdot \mathrm{VCD}_{i, \text { cloud }}(\text { air })\right) \\
& -\mathrm{SCD}_{\text {ref }} \\
& =\mathrm{MR} \cdot \mathrm{BoxAMF}_{\text {cloud }} \cdot \mathrm{VCD}_{\text {cloud }}(\text { air })-\mathrm{SCD}_{\text {reference }} \\
& \rightarrow \\
& \mathrm{MR}=\frac{\mathrm{dSCD}+\mathrm{SCD}_{\text {reference }}}{\text { BoxAMF }_{\text {cloud }} \cdot \mathrm{VCD}_{\text {cloud }}(\text { air })} .
\end{aligned}
$$

The product BoxAMF $\mathrm{Floud}_{\text {clo }} \cdot \mathrm{VCD}_{\text {cloud }}$ (air) represents the box air mass factor for the complete cloud multiplied by the vertical column density of air inside the cloud. It depends on the CTH and CE coefficient. Its dependency on the profile (e.g. constant mixing ratio) is fixed. This enabled us to interpolate the simulated BoxAMF multiplied by the vertical column density of air (see $\mathrm{O}_{4}$ SCD in Sect. 3.1), by which the variability caused by the Monte Carlo simulation is reduced.

Because we use an inflight spectrum as reference, the unknown reference $\mathrm{SCD}_{\text {reference is subtracted automatically }}$ during the DOAS analysis (Eq. 2). It has to be added to estimate the average concentration inside the cloud (Eq. 3). In an ideal case the measurements can be used to calculate

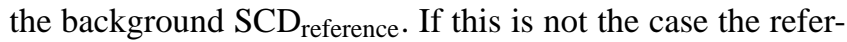
ence SCD is based on a typical background profile, either from model output or in situ data measurements. Assuming a typical background $\mathrm{NO}_{2}$ profile with a mixing ratio of 100 ppt below $2 \mathrm{~km}$ and above $9.5 \mathrm{~km}$ and $50 \mathrm{ppt}$ in between, the reference $\mathrm{SCD}_{\text {reference }}$ is $2-3 \times 10^{15}$ up to $16 \mathrm{~km}$ altitude, depending on the viewing direction. For HCHO we used the EMAC (Jöckel et al., 2010) model output to es-

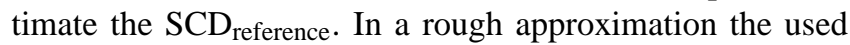
profile is an exponential decay with $700 \mathrm{ppt}$ at sea level and a scale height of $\approx 3.6 \mathrm{~km}$ and an offset of $23 \mathrm{ppt}$. Based on the profile we calculated that the reference SCD was roughly $4.4 \times 10^{15} \mathrm{molec} \cdot \mathrm{cm}^{-2}$ for $+10^{\circ}$ and 9.4 and $8.1 \times 10^{15} \mathrm{molec} \cdot \mathrm{cm}^{-2}$ for $-10^{\circ}$ and $-82^{\circ}$. Compared to the measured dSCD this adds about $30 \%$ to the measurement $\left(3 \times 10^{16} \mathrm{molec} \cdot \mathrm{cm}^{-2}\right)$. However, for HONO, only a few background measurements in the free troposphere are available, most of them close to the detection limit; also modelled results seem highly uncertain; therefore, we decided not to add any reference $\mathrm{SCD}_{\text {reference }}$ (Eq. 3).

We already mentioned in Sect. 3.1 that the interpretation of $\mathrm{O}_{4}$ dSCDs leads to an ambiguous CTH and CE. However, the variability in the length of light path is rather small, namely $\pm 5 \%$. As expected, the differences between the retrieved mixing ratios are similar, as listed in Table 4.
Table 4. Length of the light path and averaged mixing ratios of $\mathrm{HONO}, \mathrm{HCHO}$ and $\mathrm{NO}_{2}$ inside the cloud.

\begin{tabular}{rrcccc}
\hline $\begin{array}{r}\mathrm{CTH} \\
\mathrm{km}\end{array}$ & $\begin{array}{r}\mathrm{CE} \\
\mathrm{km}^{-1}\end{array}$ & $\begin{array}{c}\text { Light path } \\
\mathrm{km}\end{array}$ & $\begin{array}{r}\mathrm{HONO} \\
\mathrm{ppt}\end{array}$ & $\begin{array}{c}\mathrm{HCHO} \\
\mathrm{ppt}\end{array}$ & $\begin{array}{c}\mathrm{NO}_{2} \\
\mathrm{ppt}\end{array}$ \\
\hline 13.5 & 20.2 & 92.1 & 38.4 & 488.8 & 220.0 \\
14 & 14.4 & 94.4 & 39.0 & 497.0 & 223.8 \\
14.5 & 11.65 & 97.0 & 37.9 & 482.6 & 217.3 \\
15 & 9.85 & 99.9 & 36.3 & 462.5 & 208.3 \\
15.5 & 8.55 & 103.0 & 34.9 & 444.3 & 200.1 \\
16 & 7.6 & 106.8 & 33.9 & 431.1 & 194.1 \\
\hline
\end{tabular}

In general, the mixing ratios decrease with increasing CTH. They vary around 36.7, 468 and 210 ppt for HONO, $\mathrm{HCHO}$ and $\mathrm{NO}_{2}$ respectively. In contrast to $\mathrm{NO}_{2}$ and $\mathrm{HCHO}$, the HONO SCD is slightly enhanced before entering the cloud (Fig. 3). Although we focus on the centre of the cloud, it is interesting to mention that this slight increase might be caused by quite high HONO concentration inside and above the cloud top. Assuming a constant mixing ratio in the altitude range between $7 \mathrm{~km}$ and flight altitude $(11.6 \mathrm{~km})$, and an increase of $1.5 \times 10^{15}$ molec $\mathrm{cm}^{-2}$, results in a mixing ratio of $\approx 100 \mathrm{ppt}$. This is even higher than our results inside the cloud (37 ppt). The mathematical reason is the lower sensitivity and the smaller volume. This might indicate that the assumption of a constant mixing ratio inside the cloud is too simplified and HONO accumulates in the upper part of the cloud or above, whereas $\mathrm{HCHO}$ and $\mathrm{NO}_{2}$ can be found in the lower part.

The $\mathrm{BrO}$ detection limit of $1 \mathrm{ppt}$ for nadir and $+10^{\circ}$ is retrieved by applying the same AMF to the SCD detection limit of $6-7 \times 10^{13}$ molec $\mathrm{cm}^{-2}$. We also performed a sensitivity test on artificial spectra. We added the $\mathrm{BrO}$ cross section multiplied by the column density and some artificial random noise to the reference and found a similar value $(0.8 \mathrm{ppt})$ for the detection limit as based on the retrieval error. Hence the average $\mathrm{BrO}$ mixing ratio in this cloud was less than $1 \mathrm{ppt}$.

\subsection{Error estimates}

In Table 2 the typical DOAS retrieval errors are listed for the three lines of sight and the retrieved trace gases. These errors obviously cause an error in the retrieved mixing ratios of $\mathrm{HONO}, \mathrm{HCHO}$ and $\mathrm{NO}_{2}$. If we assume an uncertainty of $20 \%$ this adds an error of $20 \%$ to the HONO mixing ratio and $16 \%$ error to the mixing ratios of $\mathrm{HCHO}$ and $\mathrm{NO}_{2}$. The difference is caused by the different reference SCDs.

In the retrieval of the mixing ratios we added a calculated reference SCD to the measurements (Eq. (3)). Here a lot of additional information is included and we are confident that the error is small. Nevertheless, the assumed SCD contains some uncertainties which add to the total error of the mixing ratio. If we assume an uncertainty of $10 \%$, this propagates to the error of the mixing ratio as $2 \%$. 
The light path estimate (Sect. 3.1) is based on the retrieved $\mathrm{O}_{4} \mathrm{SCD}$; hence the error in the $\mathrm{O}_{4}$ column density (5-10\%) influences the mixing ratios of all trace gases. To estimate the influence of the $\mathrm{O}_{4}$ error on the retrieval we added $\pm 15 \%$ (slight overestimation) to the retrieved column density, and compared these data to the simulated $\mathrm{O}_{4} \mathrm{SCD}$. However, the influence was found to be small: for a CTH of $15 \mathrm{~km}$ the $\mathrm{CE}$ is 10.75 instead of $9.85 \mathrm{~km}^{-1}$. The change in the mixing ratios of the other trace gases caused by this change in the $\mathrm{O}_{4} \mathrm{SCD}$ is listed in Table 5. Overall it can be estimated to be $2.5 \mathrm{ppt}$ for $\mathrm{HONO}, 34 \mathrm{ppt}$ for $\mathrm{HCHO}$ and $15 \mathrm{ppt}$ for $\mathrm{NO}_{2}$. If we use the uncorrected $\mathrm{O}_{4}$ column densities in the retrieval, the averaged mixing ratios are $33.3 \mathrm{ppt} \mathrm{HONO}$, 423 ppt $\mathrm{HCHO}$ and $190.5 \mathrm{ppt} \mathrm{NO}_{2}$.

The statistical error caused by the Monte Carlo algorithm is $2 \%$ as estimated by the radiative transfer model McArtim itself. The residual of the 2-D polynomial fit for the $\mathrm{O}_{4}$ column densities, however, was $\pm 1.50 \times 10^{42} \mathrm{molec}^{2} \mathrm{~cm}^{-5}$. So the influence on the retrieved mixing ratios is of the same size as the error of the $\mathrm{O}_{4}$ column densities. The comparison of the simulated with the measured $\mathrm{O}_{4} \mathrm{SCD}$ leads to an ambiguous result, which causes an uncertainty in the inferred mixing ratios of $5 \%$ (Table 4 ).

Up to this point we had assumed a constant mixing ratio throughout the cloud (1 km to CTH). A large uncertainty, however, results from the unknown distribution of the trace gases in the cloud. Therefore, we made additional estimates using other profiles: the first profile assumes a constant mixing ratio above $8 \mathrm{~km}$ and zero below $8 \mathrm{~km}$. The second one confines HONO to the uppermost $2 \mathrm{~km}$ of the cloud (12.5$14.5 \mathrm{~km}$ ). The third one prescribes a constant mixing ratio for $\mathrm{NO}_{2}$ below $6 \mathrm{~km}$ and an exponential decrease (scale height $3 \mathrm{~km}$ ) up to the cloud top. The inferred mixing ratios are listed in Table 6.

While only a moderate increase $(\approx 25 \%)$ is found if the mixing ratio is constant above $8 \mathrm{~km}$, the HONO mixing ratio increases up to $160 \mathrm{ppt}$ if $\mathrm{HONO}$ is concentrated in the uppermost $2 \mathrm{~km}$. The DOAS instrument is less sensitive for trace gases at lower altitudes, therefore if most of the $\mathrm{NO}_{2}$ is below $6 \mathrm{~km}$, the same slant column density can only be explained by much higher concentrations i.e. $580 \mathrm{ppt}$ below $6 \mathrm{~km}$ followed by the exponential decrease. All these profiles are more or less arbitrary and give a rough estimate on the variability of the possible profiles and the corresponding mixing ratios. The real profiles for the three observed trace gases are unknown and might be different from one another. According to the chemistry described in Sect. 1, different profiles for $\mathrm{HONO}$ and $\mathrm{NO}_{2}$ are rather likely. Because the profiles are highly uncertain and the respective errors in mixing ratios at flight altitude are large, we used a representative range for the individual trace gases in our simulation.

The total error including the profile uncertainty is hard to estimate. Therefore, we included a constant mixing ratio profile above $8 \mathrm{~km}$ in the error estimate given in Table 7. Based on all the uncertainties discussed above, the total error is estimated as $\approx+30$ to $-25 \%$.

\section{Sources of nitrogen oxides, nitrous acid and formaldehyde}

To recapitulate, on the flight to Caracas on 16 August 2011 a large thunderstorm cloud was intersected. Inside the cloud NO (1.3 ppb), $\mathrm{NO}_{2}$ (210 ppt), HONO (37 ppt) and HCHO (468 ppt) were enhanced. Next we will explore the possible sources.

Although one has to be cautious with using backtrajectories inside convective systems, we note that all trajectories calculated with TRAJKS originate from the east, i.e. from the central Atlantic $\left(15-18^{\circ} \mathrm{N}, 30-60^{\circ} \mathrm{W}\right)$ and low altitudes. Hence the system followed the typical pathway of easterly waves during the summer hurricane season. As a consequence, no significant updraught of $\mathrm{NO}$ or HONO can be expected. Moreover, the lifetime of HONO ( $\leq 5 \mathrm{~min})$ is far too short for it to be transported over a longer distance, so that we expect the enhancement to be caused by local photochemistry. An updraught of HCHO is, however, possible as the marine background mixing ratios of $\mathrm{HCHO}$ reach up to 800 ppt (Sect. 5.3.1).

\subsection{Nitrogen oxides}

Both the high variability in the NO mixing ratios and the clean air origin of the air masses lead to the conclusion that the observed NO might originate from lightning. Data from the World Wide Lightning Location Network (http://wwlln. net, March 2013) indicate strong lighting activity in this area during the hours prior to the measurement. Figure 5 shows the registered flashes in the last $3.5 \mathrm{~h}$ prior to the CARIBIC measurements. There had been strong activity just east of the flight track in the last hour, which was still ongoing when our measurements took place (therefore the next $15 \mathrm{~min}$ are included). The distance between the flight track and the area of the strong lightning was about $0.4^{\circ}(\mathrm{E}-\mathrm{W})$ or roughly $40 \mathrm{~km}$. According to the ARINC data the wind speed was roughly $18 \mathrm{~m} \mathrm{~s}^{-1}$ from the east $\left(75-80^{\circ}\right)$, so the distance corresponds to a transport time of $37 \mathrm{~min}$. The flash density upwind of the flight track varied between 0.28 and 11.14 flashes per $100 \mathrm{~km}^{2}$ and hour with an average of 1.8 and a median of 1.14. According to Beirle et al. (2010, Fig. 3a) the detection efficiency (DE) of the WWLLN varies between 15 and $20 \%$ in this region. The data shown in Fig. 5 are uncorrected, but for the source estimate in Sect. 5.4.1 the flash density is multiplied by $5.5(18 \% \mathrm{DE})$.

Lightning is thus the likely source for the observed enhancements in the $\mathrm{NO}(1.3 \mathrm{ppb})$ and $\mathrm{NO}_{2}(210 \mathrm{ppt})$ mixing ratios. A box model simulation (Sect. 5.4.1) showed that a lightning density of $\approx 6$ flashes $/\left(100 \mathrm{~km}^{2} \mathrm{~h}\right)$ is sufficient to explain the observed NO mixing ratios. 
Table 5. Cloud extinction coefficients for $\mathrm{O}_{4} \mathrm{SCD}$ errors of -15 and $+15 \%$, and the corresponding range of mixing ratios for $\mathrm{HONO}$, $\mathrm{HCHO}$ and $\mathrm{NO}_{2}$. For comparison the extinction coefficient for the uncorrected $\mathrm{O}_{4} \mathrm{SCD}$ is given. For a CTH of $13.5 \mathrm{~km}$, the cloud extinction is out of the range of the simulations, therefore no values are given for the respective mixing ratios.

\begin{tabular}{|c|c|c|c|c|c|c|c|}
\hline CTH & $\mathrm{km}^{-1}$ & $\begin{array}{r}\mathrm{CE} \\
(-15 \%) \\
\mathrm{km}^{-1}\end{array}$ & $\begin{array}{r}\mathrm{CE} \\
(+15 \%) \\
\mathrm{km}^{-1}\end{array}$ & $\begin{array}{r}\mathrm{CE} \\
\text { (uncorrected) } \\
\mathrm{km}^{-1}\end{array}$ & HONO & $\mathrm{HCHO}$ & $\mathrm{NO}_{2}$ \\
\hline 13.5 & 20.2 & 17.35 & $>25$ & $>25$ & $<42$ & $<533$ & $<240$ \\
\hline 14 & 14 & 13.05 & 16 & 17.2 & $36-42$ & $461-532$ & $208-240$ \\
\hline 14.5 & 11.65 & 10.6 & 12.75 & 13.55 & $35-40$ & $452-515$ & $203-232$ \\
\hline 15 & 9.85 & 8.95 & 10.75 & 11.4 & $34-39$ & $435-492$ & $196-222$ \\
\hline 15.5 & 8.55 & 7.75 & 9.35 & 9.9 & $33-37$ & $419-472$ & $188-212$ \\
\hline 16 & 7.6 & 6.9 & 8.3 & 8.8 & $32-36$ & $408-455$ & $184-205$ \\
\hline
\end{tabular}

Table 6. Influence of the profile shape on the retrieved mixing ratios. For the fourth profile the constant $\mathrm{NO}_{2}$ mixing ratio below $6 \mathrm{~km}$ is given.

\begin{tabular}{lccc}
\hline Profile shape & $\begin{array}{c}\mathrm{HONO} \\
{[\mathrm{ppt}]}\end{array}$ & $\begin{array}{c}\mathrm{HCHO} \\
{[\mathrm{ppt}]}\end{array}$ & $\begin{array}{c}\mathrm{NO}_{2} \\
{[\mathrm{ppt}]}\end{array}$ \\
\hline Constant mixing ratio $(1 \mathrm{~km} . . \mathrm{CTH})$ & 36.7 & 467.7 & 210.6 \\
Constant mixing ratio $(8 \mathrm{~km} . . \mathrm{CTH})$ & 46.5 & 591.5 & 266.2 \\
Topmost $2 \mathrm{~km}(12.5-14.5 \mathrm{~km})$ & 160 & & \\
Constant $\left.\times \exp \frac{-(z-6 \mathrm{~km})}{3 \mathrm{~km}}\right)(z>6 \mathrm{~km})$ & & & 579.9 \\
\hline
\end{tabular}

Table 7. Overview of different error sources and the influence on the retrieved mixing ratios. To estimate the error of the profile a constant mixing ratio above $8 \mathrm{~km}$ was used here.

\begin{tabular}{lrrr}
\hline Error [ppt] & HONO & HCHO & $\mathrm{NO}_{2}$ \\
\hline Standard values & 36.7 & 467.7 & 210.6 \\
\hline DOAS retrieval & \pm 7 & \pm 80 & \pm 35 \\
Reference SCD & + & \pm 10 & \pm 4 \\
$\mathrm{O}_{4}$ SCD & \pm 2.5 & \pm 30 & \pm 12 \\
CTH-CE & \pm 1.9 & \pm 25.5 & \pm 16 \\
Simulation & \pm 2.5 & \pm 27 & \pm 12 \\
Profile & +10 & +100 & +50 \\
\hline Total & $+12.6,-10.4$ & $+155,-93$ & $+71.1,-44.2$ \\
\hline
\end{tabular}

As mentioned in the Introduction (Sect. 1) the Leighton ratio $\mathrm{NO} / \mathrm{NO}_{2}$ is important for the fate of $\mathrm{OH}$. In steady state the Leighton ratio may also be calculated via the $\mathrm{O}_{3}$ concentration and the simulated actinic flux. We used a modelled actinic flux from the Tropospheric Ultraviolet and Visible (TUV) Radiation Model (quick TUV calculator http: //cprm.acd.ucar.edu/Models/TUV/Interactive_TUV/, March 2013). To mimic the brightness of the cloud, a surface albedo of 1 was assumed. An ozone column of $250 \mathrm{DU}$ was included, based on SCIAMACHY data (www.iup.uni-bremen. de/scia-arc/, March 2013). Compared to a clear sky scenario $\left(\mathrm{j}_{\mathrm{NO}_{2}}=0.0127\right)$ with a ground albedo of $5 \%$ the actinic flux is roughly double $\left(\mathrm{j}_{\mathrm{NO}_{2}}=0.0253\right)$ (in the range of radiation enhancements in clouds given by Brasseur et al., 2002). For comparison, the intensity measured by the DOAS spectrographs in the cloud was two to three times as high as in the reference spectrum over the Atlantic ocean.

Dividing the in situ NO measurements by the DOAS $\mathrm{NO}_{2}$ observations results in a rather low Leighton ratio $(\approx 7)$. Compared to the estimates of the Leighton ratio (up to 30) based on a simulated actinic flux and the measured $\mathrm{O}_{3}$ concentrations the ratio is a factor of 4 lower. Hence we have to assume that the local $\mathrm{NO}_{2}$ concentrations are a quarter of our DOAS observations. The main reason might be that different air masses were observed by the NO and the DOAS instruments, because of the long light path of the DOAS of roughly $100 \mathrm{~km}$. Moreover, the actinic flux may be overestimated, especially for the lower parts of the cloud, which also contributes to the observed $\mathrm{NO}_{2} \mathrm{SCD}$. The difference between the observed and estimated Leighton ratios indicates that the assumption of a constant $\mathrm{NO}_{2}$ profile was too simple. If we use the $\mathrm{NO}_{2}$ profile described in Sect. 4 with a constant mixing ratio up to $6 \mathrm{~km}$ and an exponential decrease above, the mixing ratio at flight altitude $(11.6 \mathrm{~km})$ is $90 \mathrm{ppt}$, which is much closer to the $\mathrm{NO}_{2}$ data based on the Leighton ratio.

\subsection{Nitrous acid and $\mathrm{OH}$}

In the previous section we explained that lightning is probably the dominant $\mathrm{NO}_{\mathrm{x}}$ source. But also $\mathrm{HONO}$ and $\mathrm{OH}$ are produced with the lightning flashes (Bhetanabhotla et al., 1985). According to their simulations the $\mathrm{OH}$ concentration increases up to $4 \times 10^{8}$ molec $\mathrm{cm}^{-3}$ during the first millisecond after the flash. Of course the $\mathrm{OH}$ radical rapidly reacts with other species and is thereby destroyed, but most of these products just store the $\mathrm{OH}$ radical temporarily, e.g by conversion to HONO (Sect. 1). On a longer timescale (1 s) Bhetanabhotla et al. (1985) predicted a HONO to NO production rate by flashes of $6.7 \times 10^{-3}$. If we neglect additional sources of $\mathrm{HONO}$ or $\mathrm{NO}$, the initial HONO mixing ratios caused by lighting amount to $\approx 10 \mathrm{ppt} \mathrm{HONO}$, based on the observed NO mixing ratio and the simulated HONO to NO ratio. After longer time periods (minutes) HONO, NO and 

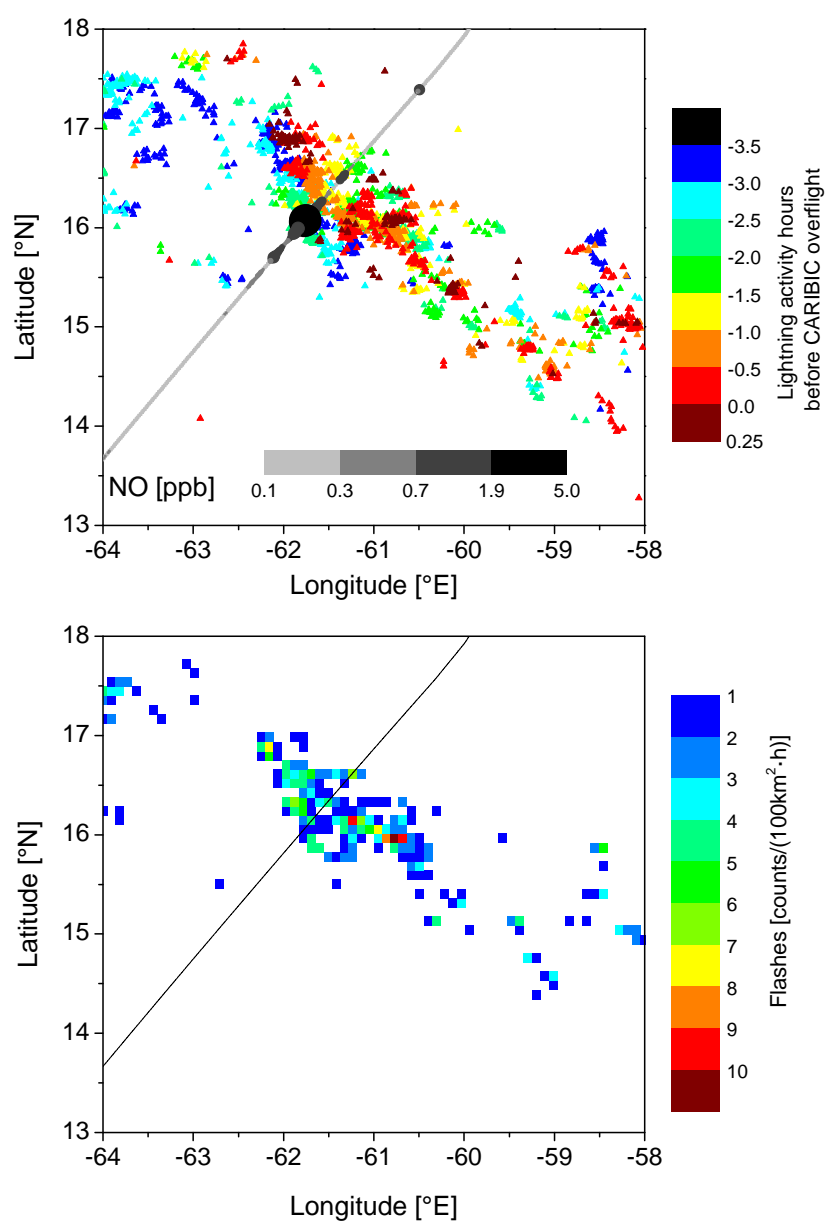

Figure 5. Top: Flashes (one point per registered flash) according to World Wide Lightning Location Network (http://wwlln.net) colour coded with the time difference to the CARIBIC overflight (18:26 UTC). To illustrate the ongoing activity also the next $15 \mathrm{~min}$ after CARIBIC penetrated the cloud are included. The grey line illustrates the CARIBIC flight track colour coded with the $10 \mathrm{~s}$ averaged NO data. The maximum NO is observed on the edge (southwest) of the lightning activity area. Bottom: flash density in flashes per $100 \mathrm{~km}^{2}$ and hour for the last $3.5 \mathrm{~h}$ prior to the CARIBIC overpass. The detection efficiency of $18 \%$ is not considered in this figure.

$\mathrm{OH}$ will reach a photo-stationary state. Despite the different air masses for HONO and NO measurements (Sect. 5.1), we assume $\mathrm{HONO}, \mathrm{NO}$ and $\mathrm{OH}$ to have been in photo-stationary steady state defined by the reactions (R2), (R3) and (R4) (Sect. 1). Thus we can estimate the $\mathrm{OH}$ concentration at flight altitude:

$[\mathrm{OH}]=\frac{J_{\mathrm{R} 3} \cdot[\mathrm{HONO}]}{k_{\mathrm{R} 2} \cdot[\mathrm{NO}]+k_{\mathrm{R} 4} \cdot[\mathrm{HONO}]}$.

This calculation results in an $\mathrm{OH}$ concentration of $1.5 \times$ $10^{7}$ molec $\mathrm{cm}^{-3}$ or $2.3 \mathrm{ppt}$ at flight altitude. Because additional HONO sources (e.g. outgassing during freezing) are not considered, the $\mathrm{OH}$ concentration might be underesti- mated. Stickler et al. (2006) retrieved $\left(1.9 \times 10^{7}\right)$ molec $\mathrm{cm}^{-3}$ from the CAABA box model for a convective system over Europe and speculated that the model might overestimate the $\mathrm{OH}$ concentrations. We applied the same model and simulated $4.8 \mathrm{ppt} \mathrm{OH}$ at flight altitude for the in-cloud conditions (Table 9).

\subsection{Formaldehyde}

In the following we will try to estimate the source strength of individual potential $\mathrm{HCHO}$ sources, i.e. updraught of boundary layer $\mathrm{HCHO}$ and chemical production by methane oxidation. In doing so, several assumptions have to be made and literature data used, even though the present study is one of few available at flight altitude. A more detailed model is used in Sect. 5.4 to quantify our estimates.

\subsubsection{Updraught from the boundary layer}

For the free and upper troposphere, formaldehyde mixing ratios of $500 \mathrm{ppt}$ and more have been reported (e.g. Fried et al., 2008a; Klippel et al., 2011; Apel et al., 2012). Often convective transport of $\mathrm{HCHO}$ itself or reactive hydrocarbons are mentioned as sources. Our observations took place in a strong convective system over a clean marine area. Background levels of formaldehyde in the marine boundary layer are about 500-900 ppt (Fried et al., 2008a), and for remote regions like the central Pacific even values as low as $200 \mathrm{ppt}$ were observed (Fried et al., 2003). According to the global chemistry climate model EMAC (Jöckel et al., 2010) the 5-day average $\mathrm{HCHO}$ mixing ratio in the marine boundary layer around Guadeloupe in August is about $600-800 \mathrm{ppt}$, of which $88 \%$ is caused by methane oxidation (S. Gromov, personal communication, 2013). In contrast to HCHO, the marine background NO is merely $\approx 100$ ppt. In Sect. 5.1 we assumed the NO updraught to be negligible, and based on the background mixing ratio close to the surface this is still justified, even though we assume updraught to be a major $\mathrm{HCHO}$ source at flight altitude. In the CAABA box model simulation a regular HCHO input of $121 \times 10^{9}$ molec $\mathrm{cm}^{-2} \mathrm{~s}^{-1} \mathrm{~km}^{-1}$ has to be included to explain the retrieved $\mathrm{HCHO}$ mixing ratio of $400 \mathrm{ppt}$ in the model.

\subsubsection{Oxidation of methane and other hydrocarbons}

An obvious source of $\mathrm{HCHO}$ is the reaction of $\mathrm{CH}_{4}$ with $\mathrm{OH}$ and subsequent reactions, in steady state:

$[\mathrm{HCHO}] \cdot k_{9} \cdot[\mathrm{OH}]+$

$[\mathrm{HCHO}] \cdot\left(J_{1}+J_{2}\right)=k_{10} \cdot[\mathrm{OH}] \cdot\left[\mathrm{CH}_{4}\right]$.

Under background conditions $\left(3 \times 10^{6}\right.$ molec $^{-3}$ of $\mathrm{OH}$ and $\mathrm{HCHO}$ photolysis frequencies of $0.6 \times 10^{-4}$ and $0.55 \times$ $10^{-4} \mathrm{~s}^{-1}$ ) the HCHO mixing ratio is $36 \mathrm{ppt}$, comparable to $40 \mathrm{ppt}$ from Fried et al. (2003) over the Pacific. For the background profile we assumed a mixing ratio of $50 \mathrm{ppt}$ 
at flight level. For the conditions inside the cloud $(1.5 \times$ $10^{7}$ molec $\mathrm{cm}^{-3} \mathrm{OH}$ and the photolysis rate being doubled), a HCHO mixing ratio of $69 \mathrm{ppt}$ is found. The increase is mainly caused by the higher $\mathrm{OH}$ concentrations (factor of 4), compared to the background conditions. In the direct vicinity of the flashes the $\mathrm{OH}$ concentration might be higher and therefore real $\mathrm{HCHO}$ due to methane oxidation might be slightly higher.

The methane oxidation reaction chain as well as other VOC reactions (see supplement) were also included in the CAABA box model simulation, but this source is found to be too weak - only $121 \mathrm{ppt} \mathrm{HCHO}$ were simulated in the NO only emission scenario (Table 9). Therefore, additional updraught of $\mathrm{HCHO}$ or of its precursors such as isoprene is found to be necessary to reach the observed $\mathrm{HCHO}$ mixing ratio of $400 \mathrm{ppt}$ in the model.

\subsubsection{Altitude effects}

DOAS measurements average over a long light path and a wide altitude range. Up to now we assumed the $\mathrm{HCHO}$ and HONO mixing ratios to be constant inside the cloud and on the other hand we assumed the $\mathrm{HCHO}$ to be formed close to flight altitude. If the formaldehyde was formed at lower altitudes this would change the reaction coefficients. At $6 \mathrm{~km}$ the temperature is $-7^{\circ} \mathrm{C}$, so the calculations (Eq. 5) result in 123 and $209 \mathrm{ppt}$, for low $\left(3 \times 10^{6} \mathrm{molec} \cdot \mathrm{cm}^{-3}\right)$ and high $\left(1.5 \times 10^{7} \mathrm{molec} \cdot \mathrm{cm}^{-3}\right) \mathrm{OH}$ respectively. Here we neglected the decrease of the photolysis rate inside the cloud. Within the strong convection this enhancements may be transported to higher altitudes quickly. This effect is not considered in the CAABA box model simulation, where just a regular additional input of $\mathrm{HCHO}$ from below the flight altitude is assumed. This input might be interpreted as direct updraught from the boundary layer or production at lower altitudes.

\subsection{CAABA box model simulations}

The CAABA chemical box model was used to simulate the chemical processes within the cloud and to estimate the source strength of lightning NO and updraught $\mathrm{HCHO}$. We do not expect chemical steady state under the extreme meteorological conditions beyond a few hours, but temporary chemical regimes with very fast chemistry due to intense photolysis, $\mathrm{HO}_{\mathrm{x}}$ and $\mathrm{NO}_{\mathrm{x}}$ chemistry.

Mixing ratios from the CARIBIC measurements (Table 3) outside and inside the cloud were taken for the background and the emission scenarios, respectively. The longer-lived tracers with lifetimes on the order of days were fixed to their initial values to allow shorter-lived tracers to adjust accordingly in steady-state calculations. The steady state of the system was defined by a relative concentration change for $\mathrm{OH}, \mathrm{NO}, \mathrm{HONO}, \mathrm{HCHO}$ and $\mathrm{NO}_{2}$ of less than $10^{-6}$ within $15 \mathrm{~min}$.
Fixed species included $\mathrm{N}_{2}, \mathrm{O}_{2}, \mathrm{H}_{2} \mathrm{O}, \mathrm{O}_{3}, \mathrm{CO}, \mathrm{CO}_{2}, \mathrm{CH}_{4}$, $\mathrm{N}_{2} \mathrm{O}, \mathrm{C}_{2} \mathrm{H}_{2}, \mathrm{C}_{2} \mathrm{H}_{6}, \mathrm{C}_{3} \mathrm{H}_{8}, \mathrm{n}-\mathrm{C}_{4} \mathrm{H}_{10}, \mathrm{CH}_{3} \mathrm{COCH}_{3}, \mathrm{CH}_{3} \mathrm{OH}$, and $\mathrm{H}_{2}$. Ozone was included in the set of fixed species following Prather and Jacob (1997) and 3-D model studies that confirmed the strong influence by transport and little influence by local photochemistry (Pommereau et al., 2011). Hydrogen levels were fixed at $510 \mathrm{ppt}$, as typically observed at $16^{\circ} \mathrm{N}$ in the upper troposphere (Batenburg et al., 2012). Among others, the nitrogen species observed by DOAS were not fixed and were free to vary according to box model conditions.

In a first step background upper tropospheric conditions were simulated as steady state using the respective clear sky photolysis frequencies (Sec. 5.1). The initial mixing ratios of $\mathrm{NO}$ and $\mathrm{NO}_{2}$ were adapted until $\mathrm{NO}$ equilibrated at around $150 \mathrm{ppt}$ as observed before entering the cloud. The background simulation equilibrated for 40 days.

In a second step a regular input of NO in every $15 \mathrm{~min}$ model time step was used to simulate the lightning NO emissions necessary to maintain the elevated background of $1.3 \mathrm{ppb} \mathrm{NO}$ in the cloud. Because the HCHO concentration was too low in background and NO emission scenarios (Table 9), we additionally simulated the simultaneous updraught of $\mathrm{HCHO}$ or its precursors $\mathrm{CH}_{3} \mathrm{OOH}$ or isoprene. Note that only one of these three $\mathrm{HCHO}$ sources was included at a time. The included sources and the source strengths necessary to explain our results are listed in Table 8 . To estimate the uncertainty of the emissions, the final $\mathrm{HCHO}$ and $\mathrm{NO}$ mixing ratios were varied in a range of 300 to $500 \mathrm{ppt}$ and 0.8 to $1.7 \mathrm{ppb}$, respectively (scenarios 6-6f in Table 9).

Based on the model, we retrieved an NO source strength of $4.6 \times 10^{9}$ molec $\mathrm{cm}^{-2} \mathrm{~s}^{-1} \mathrm{~km}^{-1}$ for the altitude range around flight altitude, if only NO emissions are considered. However, the modelled mixing ratios of $\mathrm{HCHO}$ and $\mathrm{HONO}$ were lower than the observations (Fig. 6).

The simulation of VOC emissions without NO emissions depleted the system in NO (Fig. 6) and with respect to the simulation time (Table 9), it took about 1 day to reach $400 \mathrm{ppt} \mathrm{HCHO}$, probably longer than the typical turnover time in a thunderstorm. These results might be representative for strong convection without lightning (NO emissions) and agree quite well with other findings (e.g. Fried et al., 2008b).

Only a combination of lightning NO and updraught of $\mathrm{HCHO}, \mathrm{CH}_{3} \mathrm{OOH}$ or isoprene explains both the enhanced $\mathrm{NO}$ measurements and the $\mathrm{HCHO}$ and HONO observations. The difference between these three VOCs on the estimated $\mathrm{NO}$ emissions is rather small. It varies between 7.4 for $\mathrm{NO}$ plus isoprene, to 8.5 for $\mathrm{NO}$ plus $\mathrm{CH}_{3} \mathrm{OOH}$ and $10 \times 10^{9} \mathrm{NO}$ molec $\mathrm{cm}^{-2} \mathrm{~s}^{-1} \mathrm{~km}^{-1}$ for NO plus HCHO. Due to the uncertainties in the $\mathrm{HCHO}$ mixing ratios caused by the assumed profile and background (Sect. 4) we varied the $\mathrm{HCHO}$ mixing ratios at flight level between 300 and $500 \mathrm{ppt}$ (scenarios 6e and $\mathrm{f}$ ). This caused a variation in the NO source strength of between 8 and $11.6 \times 10^{9} \mathrm{NO}$ molec $\mathrm{cm}^{-2} \mathrm{~s}^{-1} \mathrm{~km}^{-1}$. We did not include the observed variations in $\mathrm{NO}$ here, because these 
Table 8. Box model emission scenarios. NO emissions were adjusted to target the median mixing ratio of $1300 \mathrm{ppt}$ for NO as observed in situ by CARIBIC within the cloud. VOC emissions of $\mathrm{HCHO}, \mathrm{CH}_{3} \mathrm{OOH}$ and isoprene were tuned to reach $400 \mathrm{ppt}$ of $\mathrm{HCHO}$, the most likely mixing ratio within the cloud according to DOAS observations. We define $1300 \mathrm{ppt}$ of NO and $400 \mathrm{ppt}$ of HCHO as the standard for the situation within the cloud. However, NO and VOC emissions were also varied simultaneously to yield the first and third quartile for NO (0.8-1.7 ppb), and the uncertainty lower and upper limit (300-500 ppt) for HCHO (scenarios 6b-6i). The box model height was fixed to $1 \mathrm{~km}$ for the conversion between area and volume emissions.

\begin{tabular}{|c|c|c|c|c|c|c|}
\hline \multirow{2}{*}{$\begin{array}{l}\text { Scenario } \\
\text { (emitted species) }\end{array}$} & \multicolumn{2}{|c|}{ Target species [ppt] } & \multicolumn{4}{|c|}{ Emissions $\left(10^{9}\right.$ molec $\left.\mathrm{cm}^{-2} \mathrm{~s}^{-1} \mathrm{~km}^{-1}\right)$} \\
\hline & NO & $\mathrm{HCHO}$ & NO & $\mathrm{HCHO}$ & $\mathrm{CH}_{3} \mathrm{OOH}$ & isoprene \\
\hline $2 \mathrm{NO}$ & 1300 & - & 4.6 & - & - & - \\
\hline $3 \mathrm{HCHO}$ & - & 400 & - & 84.6 & - & - \\
\hline $4 \mathrm{CH}_{3} \mathrm{OOH}$ & - & 400 & - & - & 70 & - \\
\hline 5 isoprene & - & 400 & - & - & - & 40.3 \\
\hline $6 \mathrm{a} \mathrm{NO}+\mathrm{HCHO}$ & 1300 & 400 & 10.0 & 121 & - & - \\
\hline $\mathrm{b} \mathrm{NO}+\mathrm{HCHO}$ & 800 & 300 & 3.7 & 66 & - & - \\
\hline $\mathrm{c} \mathrm{NO}+\mathrm{HCHO}$ & 800 & 400 & 6.0 & 111 & - & - \\
\hline $\mathrm{d} \mathrm{NO}+\mathrm{HCHO}$ & 800 & 500 & 7.5 & 161 & - & - \\
\hline e $\mathrm{NO}+\mathrm{HCHO}$ & 1300 & 300 & 8.0 & 70 & - & - \\
\hline $\mathrm{f} \mathrm{NO}+\mathrm{HCHO}$ & 1300 & 500 & 11.6 & 178 & - & - \\
\hline $\mathrm{g} \mathrm{NO}+\mathrm{HCHO}$ & 1700 & 300 & 8.0 & 71 & - & - \\
\hline h NO $+\mathrm{HCHO}$ & 1700 & 400 & 9.5 & 123 & - & - \\
\hline i $\mathrm{NO}+\mathrm{HCHO}$ & 1700 & 500 & 11.0 & 182 & - & - \\
\hline $7 \mathrm{NO}+\mathrm{CH}_{3} \mathrm{OOH}$ & 1300 & 400 & 8.5 & - & 92 & - \\
\hline $8 \mathrm{NO}+$ isoprene & 1300 & 400 & 7.4 & - & - & 35.5 \\
\hline
\end{tabular}
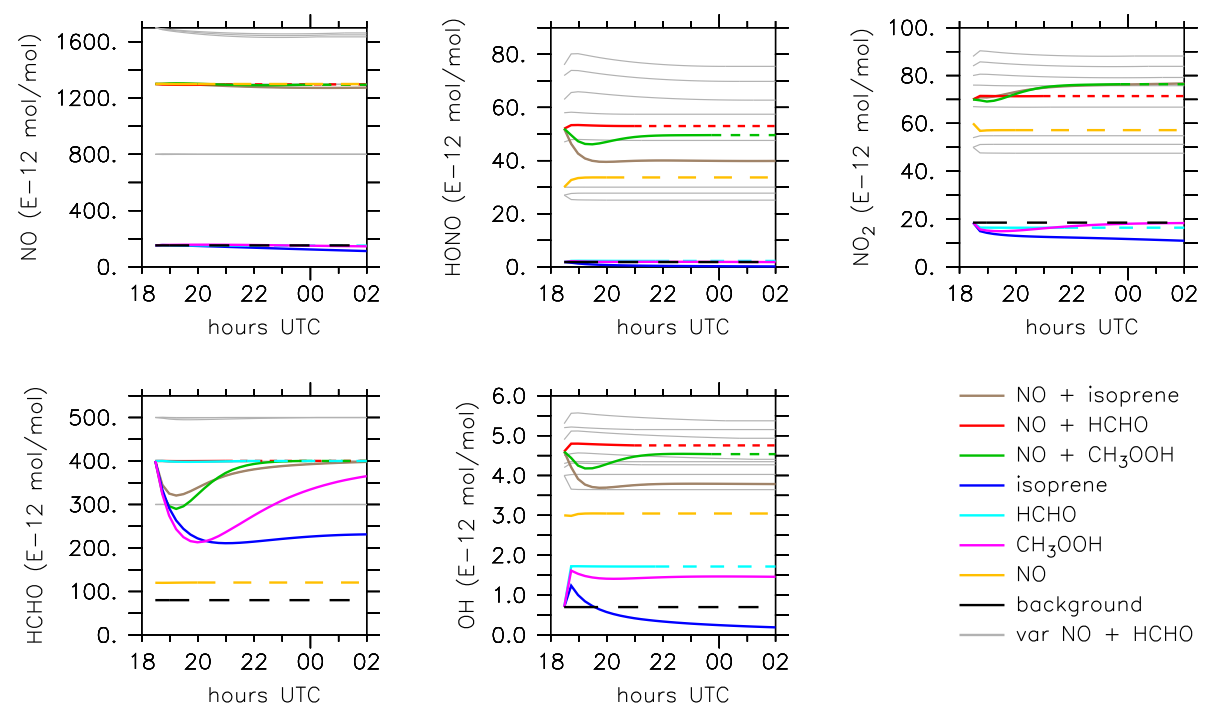

Figure 6. Simulated mixing ratios of $\mathrm{NO}, \mathrm{HONO}, \mathrm{NO}_{2}, \mathrm{HCHO}$ and $\mathrm{OH}$ as function of time for several emission (updraught) scenarios. The "+" sign in the legend denotes simultaneous emissions of both species. Grey lines show the variations of the NO $+\mathrm{HCHO}$ scenario (red line, scenarios $6 \mathrm{~b}-\mathrm{i}$ ) with NO mixing ratios varying between 800 and $1700 \mathrm{ppt}\left(\mathrm{ppt}=10^{-12} \mathrm{~mol} \mathrm{~mol}^{-1}\right.$ ), and $\mathrm{HCHO}$ mixing ratios varying between 300 and 500 ppt. Dashed lines show at which level very short steady-state simulations end. The figures for $\mathrm{HONO}$ and $\mathrm{NO}_{2}$ indicate that concomitant emissions of $\mathrm{NO}$ and one of the three VOCs enhance $\mathrm{HONO}$ and $\mathrm{NO}_{2}$ mixing ratios more than any separate $\mathrm{NO}$ or VOC emissions. The separate low levels of $\mathrm{HONO}$ and $\mathrm{NO}_{2}$ among the grey lines all belong to the scenarios with $800 \mathrm{ppt} \mathrm{NO}$.

variations do not reflect a measurement uncertainty but a local variability.

The source strengths of $\mathrm{HCHO}, \mathrm{CH}_{3} \mathrm{OOH}$ or isoprene are 121,92 and $36 \times 10^{9}$ molec $\mathrm{cm}^{-2} \mathrm{~s}^{-1} \mathrm{~km}^{-1}$, respectively (Ta- ble 8). This confirms previous studies (e.g. Stickler et al., 2006) that isoprene in combination with NO is an effective precursor of formaldehyde. A combination of the direct $\mathrm{HCHO}$ updraught and the precursors is most likely. However, 
Table 9. Overview of CAABA box model results for the standard emission scenarios listed in Table 8. The mixing ratios are given in ppt $\left(10^{-12} \mathrm{~mol} \mathrm{~mol}^{-1}\right)$. The simulation time (sim. time) is given in days (d) or hours (h) until a (temporary) steady state is reached. The background simulation was running for 40 days. Emitting isoprene increases the isoprene mixing ratios unrealistically, not so together with NO emissions.

\begin{tabular}{lrrrrrrrrrr}
\hline $\begin{array}{l}\text { Scenario } \\
\text { (emitted species) }\end{array}$ & $\mathrm{NO}$ & $\mathrm{HONO}$ & $\mathrm{NO}_{2}$ & $\mathrm{HCHO}$ & $\mathrm{CH}_{3} \mathrm{OOH}$ & $\mathrm{OH}$ & $\mathrm{HO}_{2}$ & PAN & Isoprene & $\begin{array}{c}\text { Sim. } \\
\text { time }\end{array}$ \\
\hline 1 Background & 153 & 1.8 & 18.5 & 80 & 10.6 & 0.7 & 7.6 & 102 & - & $40 \mathrm{~d}$ \\
2 NO & 1300 & 33.7 & 57.2 & 121 & 0.4 & 3 & 4.1 & 101 & - & $1.5 \mathrm{~h}$ \\
$3 \mathrm{HCHO}$ & 152 & 2.3 & 16.4 & 400 & 26.8 & 1.7 & 24.3 & 102 & - & $3.3 \mathrm{~h}$ \\
$4 \mathrm{CH}_{3} \mathrm{OOH}$ & 135 & 1.6 & 18.3 & 400 & 1144.3 & 1.4 & 28.1 & 101 & - & $18.3 \mathrm{~h}$ \\
5 Isoprene & 4 & 0 & 0.9 & 400 & 1210 & 0 & 22.9 & 314 & 3427 & $10.9 \mathrm{~d}$ \\
6a NO+ $\mathrm{HCHO}$ & 1297 & 53 & 71.4 & 400 & 1.2 & 4.8 & 7.6 & 101 & - & $2.5 \mathrm{~h}$ \\
\hline $\mathrm{b}$ & 801 & 25.1 & 47.5 & 300 & 1.8 & 3.6 & 8.9 & 101 & - & $1.5 \mathrm{~h}$ \\
$\mathrm{c}$ & 799 & 27.8 & 51.2 & 399 & 1.5 & 4 & 10.5 & 102 & - & $0.7 \mathrm{~h}$ \\
$\mathrm{~d}$ & 800 & 30 & 54.8 & 500 & 1.8 & 4.3 & 11.9 & 102 & - & $0.7 \mathrm{~h}$ \\
$\mathrm{e}$ & 1299 & 47.6 & 66.8 & 300 & 1 & 4.3 & 6.4 & 101 & - & $2.7 \mathrm{~h}$ \\
$\mathrm{f}$ & 1296 & 57.4 & 75.7 & 500 & 1.5 & 5.2 & 8.7 & 101 & - & $2.5 \mathrm{~h}$ \\
$\mathrm{~g}$ & 1663 & 62.7 & 79.2 & 300 & 0.7 & 4.4 & 5.2 & 98 & - & $6.7 \mathrm{~h}$ \\
$\mathrm{~h}$ & 1649 & 69.8 & 83.8 & 400 & 0.9 & 4.9 & 6.3 & 99 & - & $6.2 \mathrm{~h}$ \\
$\mathrm{i}$ & 1635 & 75.4 & 88.2 & 500 & 1 & 5.4 & 7.2 & 99 & - & $5.8 \mathrm{~h}$ \\
\hline $7 \mathrm{NO}+\mathrm{CH}_{3} \mathrm{OOH}$ & 1294 & 49.6 & 76.4 & 400 & 404.7 & 4.5 & 8.2 & 100 & - & $5.3 \mathrm{~h}$ \\
$8 \mathrm{NO}+$ isoprene & 1278 & 40 & 77 & 400 & 2.7 & 3.8 & 7.7 & 133 & 1 & $8.7 \mathrm{~h}$ \\
\hline & & & & & & & & & &
\end{tabular}

the partitioning between the individual sources is unknown and therefore not considered in the model. Because the estimated NO source strength slightly depends on the simulated $\mathrm{HCHO}$ precursor, we assumed the direct updraught of $\mathrm{HCHO}$ to be the major source. Therefore, we used 10(8-11.6) $\times 10^{9}$ NO molec $\mathrm{cm}^{-2} \mathrm{~s}^{-1} \mathrm{~km}^{-1}$ for the following calculations.

In Sect. 5.1 we mentioned that measured $\mathrm{NO}_{2}$ mixing ratios were higher than the estimate based on $\mathrm{NO}$ and the Leighton ratio. As expected, the modelled $\mathrm{NO}_{2}$ mixing ratios between 70 and $80 \mathrm{ppt}$ (Leighton ratio $\approx 18$ ) agree well with this estimate and are much lower than the DOAS measurements of $\mathrm{NO}_{2}$, which again indicates that the $\mathrm{NO}_{2}$ profile was more complex than previously assumed.

The turnover of HONO in the thunderstorm cloud simulation is about two orders of magnitude higher $\left(\approx 10^{-13} \mathrm{~mol} \mathrm{~mol}^{-1} \mathrm{~s}^{-1}\right)$ than in the background simulation $\left(\approx 10^{-15} \mathrm{~mol} \mathrm{~mol}^{-1} \mathrm{~s}^{-1}\right)$. The HONO mixing ratio is elevated by a factor of about 30 , reaching $53 \mathrm{ppt}$ in the simulation with $1.3 \mathrm{ppb} \mathrm{NO}$ and $400 \mathrm{HCHO}$. Across the simulations with varying mixing ratios from 0.8 to $1.3 \mathrm{ppb}$ for $\mathrm{NO}$, and from 300 to $500 \mathrm{ppt}$ for $\mathrm{HCHO}$, the enhancement factor varies from about 14 for all simulations at $0.8 \mathrm{ppb} \mathrm{NO}$ ( $\approx 26$ ppt HONO) to about 44 (83 ppt) HONO for the simulation at around $1.7 \mathrm{ppb} \mathrm{NO}$ and $500 \mathrm{ppt} \mathrm{HCHO}$. Overall, the chemical lifetime of HONO molecules decreases from $8 \mathrm{~min}$ under backgound conditions to $4 \mathrm{~min}$ under cloud conditions. In contrast to HONO studies in the lower troposphere, which emphasize the importance of heterogeneous chemistry in HONO formation, this box-model study explains the most probable HONO mixing ratios by gasphase chemistry alone. More observations are needed to confirm this overall mi- nor role of heterogeneous processes for HONO formation in thunderstorm clouds.

\subsubsection{Estimates of the lightning emission factor}

In the following we will combine the inferred $\mathrm{NO}$ source strength of $10 \times 10^{9}$ molec $\mathrm{cm}^{-2} \mathrm{~s}^{-1} \mathrm{~km}^{-1}$ (or $2.97 \times$ $10^{23}$ molec $\left.\left(\mathrm{km}^{-3} \mathrm{~h}^{-1}\right)\right)$ with the median flash density $(6.3$ flashes per $100 \mathrm{~km}^{2}$ and hour) to estimate the lighting emission factor. First the NO source strength has to be integrated over the cloud altitude range, because we calculated the source strength at flight altitude. The NO emission of lighting depends linearly on the pressure (laboratory studies by Wang et al., 1998). We used the linear dependency they found and scaled it to our volume emission $\left(10 \times 10^{9}\right.$ molec $\left.\mathrm{cm}^{-2} \mathrm{~s}^{-1} \mathrm{~km}^{-1}\right)$ at $205 \mathrm{hPa}$. Moreover, the fractioning between intracloud (IC) and cloud to ground (CG) flashes has to be considered. The ratio of CG to IC flashes was estimated to $6-15 \%$ based on the CTH (13.5$16.5 \mathrm{~km})$ and the freezing level $(4.9 \mathrm{~km})$ using the formulae cited in Pickering et al. (1998) for marine conditions. The altitude range for $\mathrm{CG}$ flashes typically reaches up to the $-15^{\circ} \mathrm{C}$ level $(7.5 \mathrm{~km})$ and for IC flashes it stretches from there to the cloud top (Mushtak et al., 2005). For the median flash density and pressure-dependent NO emissions, we calculated an NO emission factor of $5 \times 10^{25}$ molec flash $^{-1}$ if the $\mathrm{CTH}$ is $15 \mathrm{~km}$.

The emission per flash only shows a weak dependency on the CTH, i.e 4.6 or $5.6 \times 10^{25} \mathrm{NO}$ molec $\mathrm{flash}^{-1}$ for 13.5 and $16.5 \mathrm{~km}$, respectively. The flash density on the other hand has a large impact on the estimated NO emission per flash, especially as the detection efficiency (DE) of the WWLLN has to be considered. For the previous estimate we assumed 


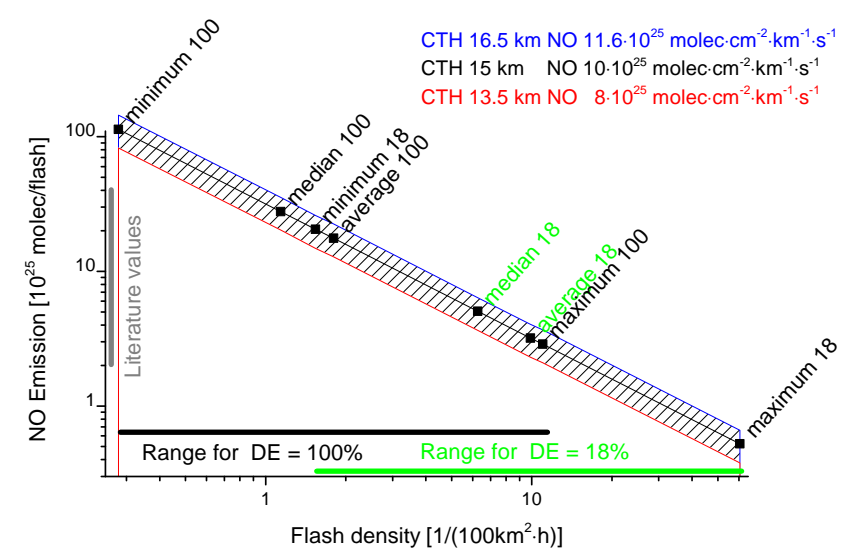

Figure 7. NO emissions per flash, depending on the flash density and the CTH. The hashed area indicates the uncertainty due to different CTHs and NO emissions. The emissions necessary to explain our observations vary between 0.4 and $141 \times 10^{25} \mathrm{NO}$ molec flash ${ }^{-1}$. However, these extreme values are retrieved using the minimum and the maximum flash density and assuming a DE of $100 \%$ for the minimum flash rate.

the $\mathrm{DE}=18 \%$, as mentioned in Sect. 5.1. The results for a large range of flash densities (Fig. 7) vary over two orders of magnitude depending on the flash density or the detection efficiency. We estimate that the most realistic values lie between 2.3 and $6.4 \times 10^{25} \mathrm{NO}$ molec flash ${ }^{-1}$, based on the average or the median flash density and a DE of $18 \%$, a CTH of 16.5 and $13.5 \mathrm{~km}$ and the NO emission rates of 8 and $11.6 \times 10^{9}$ molec $\mathrm{cm}^{-2} \mathrm{~s}^{-1} \mathrm{~km}^{-1}$ (emission scenarios 6e and f). In their review paper Schumann and Huntrieser (2007) listed emission factors in the range of $2-$ $40 \times 10^{25} \mathrm{NO}$ molec flash $^{-1}$ with an average of $15 \times 10^{25}$ $\mathrm{NO}$ molec flash ${ }^{-1}$. Our estimate is within that range though close to the lower limit.

To extrapolate these emissions to the global scale we multiplied emission per flash with the global flash frequency of $46 \mathrm{~s}^{-1}$ (Cecil et al., 2014) and obtain $1.9 \mathrm{Tg} \mathrm{N} \mathrm{a}^{-1}(1.4-2.5)$. Our HONO observations close to the flight altitude lead to the conclusion that above or inside other convective systems HONO should be found as well. This assumption is also confirmed by the fact that enhanced HONO SCDs were observed during other CARIBIC flights. According to the model simulation the enhanced mixing ratios are caused by the photochemical production initiated by lightning $\mathrm{NO}$ and updraught $\mathrm{HCHO}$, which are both available in other thunderstorms as well. We did not simulate NO as build-up from background because it is directly emitted. Local HONO production, by contrast, is much more important than the direct HONO to NO production ratio as simulated by Bhetanabhotla et al. (1985). Therefore the up-scaling of HONO production to a global scale seems unrealistic.

\section{Conclusions}

We report on an extreme event, when the CARIBIC passenger aircraft flew through a thunderstorm system. Aircraft generally avoid strong convection and lightning which means that we have few such events.

Inside the cloud long light paths are observed, as seen in the enhanced $\mathrm{O}_{4} \mathrm{SCDs}$. These SCDs were used to estimate the light path. Inside the cloud path lengths of about $100 \mathrm{~km}$ were found. Thereby the DOAS instrument on the CARIBIC platform allowed an estimate of the average mixing ratios inside the cloud: HONO $36.7 \mathrm{ppt},-10.4,+12.4 \mathrm{ppt}$, HCHO $468 \mathrm{ppt},-93,+155 \mathrm{ppt}$ and $\mathrm{NO}_{2} 210 \mathrm{ppt},-44,+71 \mathrm{ppt}$. During the flight through the cloud the NO analyser measured up to $5 \mathrm{ppb}$ with a mean of $1.48 \mathrm{ppb}$. Because the event was observed in the updraught of marine boundary layer air, we conclude that $\mathrm{NO}_{\mathrm{x}}$ was caused by lightning rather than pollution. Before the aeroplane entered the cloud it flew over a lower part of it. During this period low $\mathrm{O}_{4}$ SCDs were observed, while HONO was already enhanced. A rough estimate showed that if the HONO was situated between the cloud and the flight altitude, the local mixing ratio might have reached up to $100 \mathrm{ppt}$. Similar events (low $\mathrm{O}_{4}$ and high HONO) were also observed during other flights but only in a few cases HONO SCDs up to $1.5 \times 10^{15}$ molec $\mathrm{cm}^{-2}$ were found. However, similar mixing ratios above the cloud might be found there as well.

We used the CAABA box model to estimate the NO source strength. In the model calculations combined emissions of $\mathrm{NO}$ and $\mathrm{HCHO}$ precursors were essential to explain our findings. Direct $\mathrm{HCHO}$ updraught as well as $\mathrm{CH}_{3} \mathrm{OOH}$ and isoprene as precursors were considered. In these studies the necessary NO emissions varied only between 7.4 and $11.3 \times 10^{9}$ molec $\mathrm{cm}^{-2} \mathrm{~s}^{-1} \mathrm{~km}^{-1}$, while for the updraught of $\mathrm{HCHO}, \mathrm{CH}_{3} \mathrm{OOH}$ and isoprene 121, 92 and $36 \times 10^{9}$ molec $\mathrm{cm}^{-2} \mathrm{~s}^{-1} \mathrm{~km}^{-1}$, respectively, had to be assumed. The origin of the enhanced HCHO and HONO is a combination of updraught and enhanced chemical production initiated by lightning $\mathrm{NO}_{\mathrm{x}}$. An emission rate of $5 \times 10^{25}$ (2.3-6.4) NO molecules per flash is estimated based on the simulated NO emissions and the observed lightning density (World Wide Lightning Location Network). The NO emissions per flash result in an annual global lightning NO production of $1.9(1.4-2.5) \mathrm{Tg} \mathrm{N} \mathrm{a}^{-1}$.

The HONO production depends on the availability of $\mathrm{NO}$ and $\mathrm{HCHO}$. Here we assumed that methane oxidation followed by updraught is the major HCHO source in the tropopause. This source can be expected in every thunderstorm, though with different source strengths. Hence HONO should be observable in or above many major thunderstorms, as indicated by other occasional observations of HONO with the CARIBIC DOAS instrument. 

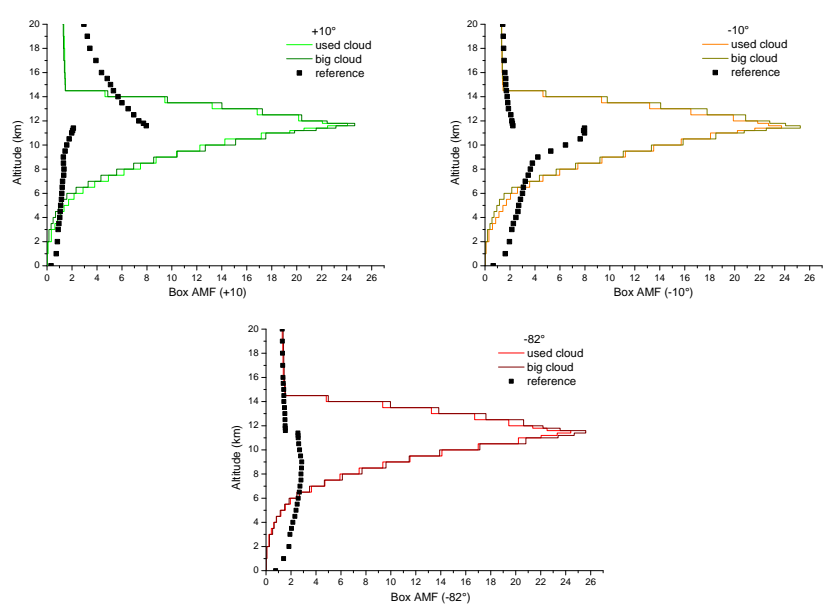

Figure A1. Box AMF for the CTH of $14.5 \mathrm{~km}$ and a CE coefficient of $13 \mathrm{~km}^{-1}$, for both the small cloud we used and a bigger (more realistic) cloud. The difference between the two box AMFs is small. In addition the Box AMFs for the reference case are shown.

\section{Appendix A: Radiative transfer modelling}

This appendix contains a more detailed description of the radiative transfer modelling inside the large cloud system the CARIBIC aeroplane crossed on the way to Caracas. A short summary of the radiative transfer modelling is given in the paper.

\section{A1 Light path estimate}

Inside the cloud the light path is extremely enhanced due to the scattering on the cloud droplets. A well-known tool to estimate the length of the light path is the comparison of modelled and observed $\mathrm{O}_{4}$ column densities (e.g. Erle et al., 1995; Wagner et al., 2004; Frieß et al., 2006; Heue, 2005). We used the 3-D radiative transfer model McArtim (Deutschmann et al., 2011) to simulate the light propagating through the cloud to the three telescopes inside the cloud. The model enabled us to simulate a 3-D cloud with cloud base of $150 \times 60 \mathrm{~km}^{2}$ with on top of it a small cloud of $50 \times 20 \mathrm{~km}^{2}$. To reduce the computer time, the cloud dimensions we assumed were smaller than the real cloud. However, for a CTH of $14.5 \mathrm{~km}$ also more realistic dimensions $(400 \times 400 \mathrm{~km})$ were considered for the cloud extinction 13 $17 \mathrm{~km}^{-1}$. The difference in the light path was about $15 \%$, which is in the range of the model's uncertainty. A direct comparison of the box AMFs is shown in Fig. A1. The model showed a high sensitivity to the position of the detector inside the cloud. Therefore, we conclude that reducing the cloud even more might cause errors in the retrieved cloud parameters.

We focused on the centre of the cloud, where the maximum of the $\mathrm{O}_{4}$ SCDs was observed (Fig. 3). The simulation aims to estimate of the cloud's extinction coefficient and the
$\mathrm{CTH}$ of the part the aeroplane passed through. These two parameters were varied in the range of 7 to $25 \mathrm{~km}^{-1}$ and 13 to $16 \mathrm{~km}$, respectively. The cloud base was fixed at $1 \mathrm{~km}$ (based on the ECMWF model data and the video camera) and the cloud top was $9 \mathrm{~km}$ except for the small part that the aeroplane intersected. Because the flight altitude was $11.6 \mathrm{~km}$, the minimum altitude for that part of the cloud was about $12 \mathrm{~km}$. According to the ECMWF data (TRAJKS model) the mixed phase (ice and liquid water) reached from 5 to $7.5 \mathrm{~km}$, therefore we assumed the water to be liquid up to $6 \mathrm{~km}$ and hence used an asymmetry factor of $g=0.85$ and $g=0.7$ for the ice cloud above $6 \mathrm{~km}$. For both water and ice cloud the singlescattering albedo of the cloud droplets was set to unity. In total we simulated over 300 clouds for three lines of sight each. Depending on the computer and the cloud properties it took up to 5 days per cloud. By multiplying the square of the local $\mathrm{O}_{2}$ concentration with respective box AMF and the box height, the $\mathrm{O}_{4} \mathrm{SCD}$ can be calculated as the sum of these products. For the comparison with the measurements the simulated $\mathrm{O}_{4}$ column densities were interpolated by a 2$\mathrm{D}(\mathrm{CTH}$ and $\mathrm{CE})$ second-order polynomial. The length of the light path and the air mass factors are interpolated in the same way.

We followed the suggestions of Wagner et al. (2009b) and Clémer et al. (2010) and corrected the measured $\mathrm{O}_{4} \mathrm{SCDs}$ with a factor of 0.8 before comparing them to the simulations. The influence of this correction is briefly discussed in Sect. 4.1 together with the uncertainty of the $\mathrm{O}_{4} \mathrm{SCD}$.

The minimum difference between the measured and the calculated $\mathrm{O}_{4}$ dSCDs should be the best approximation of the real conditions in the cloud. Therefore we subtracted the measurements from the simulated column densities for all viewing directions and calculated the root of the squared errors. However, a clear global minimum was not identified (Fig. A2), instead a local minimum for each CTH between 13.4 and $17 \mathrm{~km}$ was found.

For all three viewing directions a minimum deviation between measurement and simulation should be found for the same parameters of the cloud. This is only achieved by including the reference in the simulation. Directly below and to the right (viewing direction of the telescopes), no clouds were seen in the video data, but it was hazy, therefore we included a thin cirrus cloud at flight altitude $(9-11 \mathrm{~km})$. A reasonable but still not perfect agreement (Fig. A3) is found for a cloud extinction of $0.2 \mathrm{~km}^{-1}$ for the cirrus cloud. Mainly the $-10^{\circ}$ viewing direction deviated from the other two lines of sight. The difference of the simulated $\mathrm{O}_{4} \mathrm{dSCD}$ for $-10^{\circ}$ was independent of the simulated $\mathrm{O}_{4} \mathrm{SCD}$ of the cloud. We concluded that this effect was caused by the simulated reference and we are confident that we included the aerosol in the reference correctly. Unfortunately, it was very cloudy under the plane for most of the flight, which caused even larger problems in the simulation of the reference $\mathrm{O}_{4} \mathrm{SCD}$.

The local minima in the deviation from the measurement for each CTH between 13.5 and $16 \mathrm{~km}$ (step $0.5 \mathrm{~km}$ ) were 


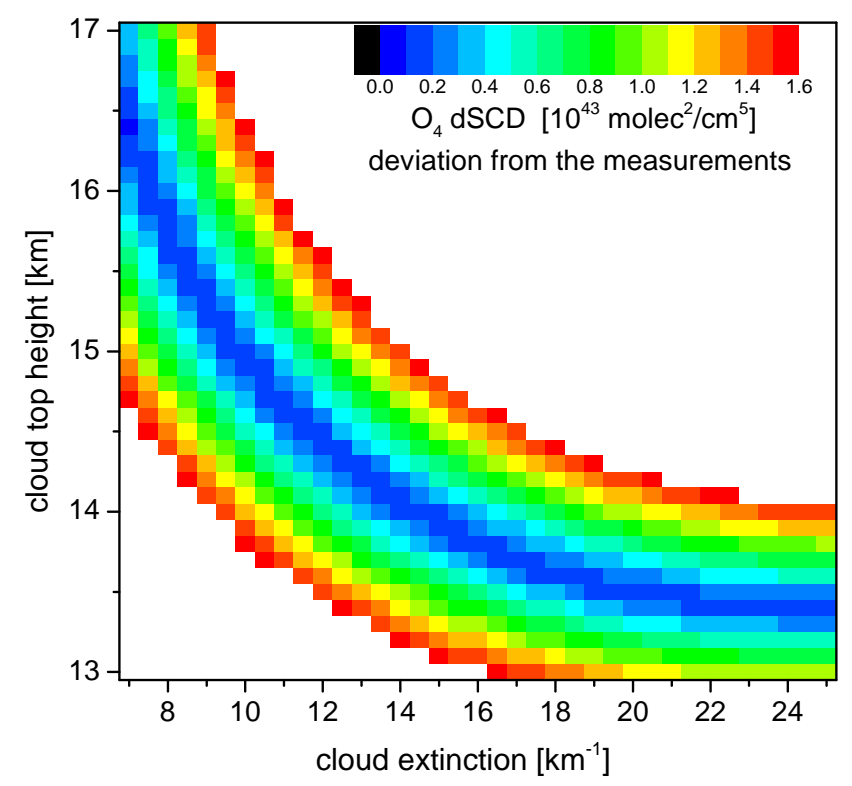

Figure A2. Colour-coded difference between the measured and the modelled $\mathrm{O}_{4} \mathrm{SCD}$ for the simulated range of CTHs and cloud extinctions. The minima describe a curve from 13.4 to $16.7 \mathrm{~km}$ and from 25 to $7 \mathrm{~km}^{-1}$

calculated. The cloud extinction coefficient varied between 20.2 and $7.6 \mathrm{~km}^{-1}$. The length of the light path ranged from $92 \mathrm{~km}$ (for $13.5 \mathrm{~km} \mathrm{CTH}$ and $20.2 \mathrm{~km}^{-1} \mathrm{CE}$ ) to $107 \mathrm{~km}$ (for $16 \mathrm{~km}$ and $\left.7.6 \mathrm{~km}^{-1}\right)$. An overview of the estimated path length is given in Table 4 together with the retrieved mixing ratios for the different trace gases.

\section{A2 Comparison with MODIS observation}

The same convective system was observed by the MODIS Aqua instrument (data available at: http://ladsweb.nascom. nasa.gov/, February 2013) at 17:20 UTC, i.e. $1 \mathrm{~h}$ prior to the CARIBIC measurements. According to these data the cloud top pressure was between 120 and $105 \mathrm{hPa}$ and the cloud top temperature (Fig. A4) between 197.5 and $200 \mathrm{~K}$, which corresponds to a CTH of 15 to $16 \mathrm{~km}$, which is at the upper end of our retrieved altitude range.

The total cloud extinction for such large and optical dense clouds is not a standard product provided by the MODIS team on the internet. Instead a minimum threshold of 100 is given. Therefore, the cloud optical thickness of the DOAS data cannot be compared to the MODIS analysis. Instead a comparison of the cloud effective radius (droplets) can be performed. It is calculated from the MODIS data giving a cloud effective radius of 20 to $24 \mu \mathrm{m}$ with an error estimate of $\pm 5 \mu \mathrm{m}$. The cloud effective radius $r$ correlates the cloud water content $w$ with the cloud extinction coefficient $k$ ac-
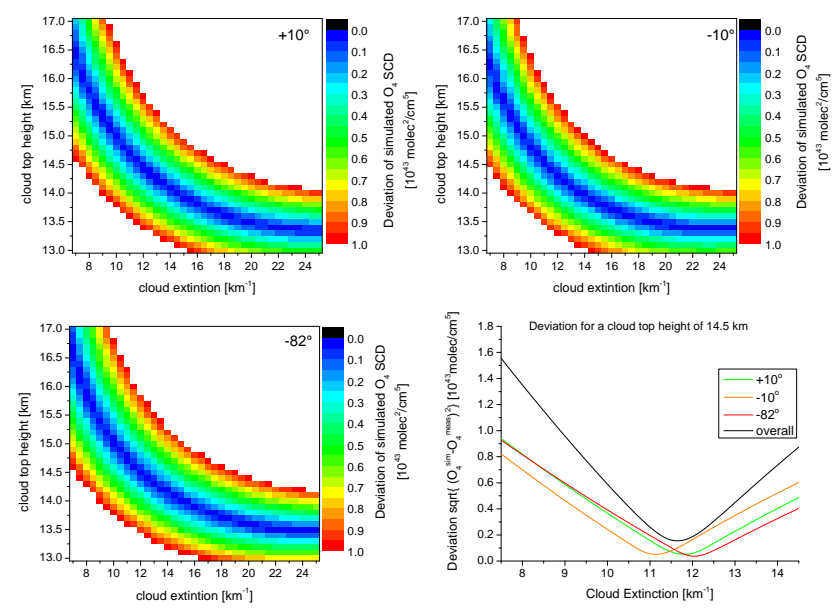

Figure A3. Similar to Fig. A2, but for the individual viewing directions. A cross section for the CTH of $14.5 \mathrm{~km}$ is shown in the bottom left. The minima for the three viewing directions are not observed at exactly the same cloud extinction, which might be caused by a small error in the simulated reference SCD.

Table A1. Cloud effective radius as a function of CTH or CE. Here we calculated with a constant cloud water content of $948 \mathrm{ppm}$. Changing the water content by $\pm 78 \mathrm{ppm}$ did not influence the effective radius significantly; the results are given as $\Delta r_{\text {eff. }}$.

\begin{tabular}{lcccccc}
\hline CTH $[\mathrm{km}]$ & 13.5 & 14 & 14.5 & 15 & 15.5 & 16 \\
$\mathrm{CE}\left[\mathrm{km}^{-1}\right]$ & 20.2 & 14.4 & 11.65 & 9.85 & 8.55 & 7.6 \\
$r_{\text {eff }}[\mu \mathrm{m}]$ & 15.3 & 21.5 & 26.6 & 31.5 & 36.2 & 40.8 \\
$\Delta r_{\mathrm{eff}}[\mu \mathrm{m}]$ & 1.3 & 1.8 & 2.2 & 2.6 & 3.0 & 3.4 \\
\hline
\end{tabular}

cording to

$k=2 \cdot N \cdot \pi \cdot r^{2}$

$w=\frac{4}{3} \cdot N \cdot \pi \cdot r^{3} \cdot \rho$.

Combining these two equations results in

$r=\frac{3 \cdot w}{2 \cdot k \cdot \rho}$

where $N$ is the number density of cloud droplets, and $\rho=0.918 \mathrm{~g} \mathrm{~cm}^{-3}$ the ice mass density. The cloud water content $w$ can be retrieved from the cloud water measurement. At flight altitude $948 \mathrm{ppm}$ (Table 3) corresponds to $0.19 \mathrm{~g}$ water per $\mathrm{m}^{3}$. Because the water content is almost constant (Fig. 2), the cloud effective radius depends on the cloud extinction $k$ only, which is a function of the CTH (Fig. A2). Hence for each CTH a cloud effective radius can be given (Table A1). The variability in the cloud water $\pm 78 \mathrm{ppm}$ changes the cloud effective radius by 1.8 to $3.5 \mu \mathrm{m}$ depending on the cloud extinction. 


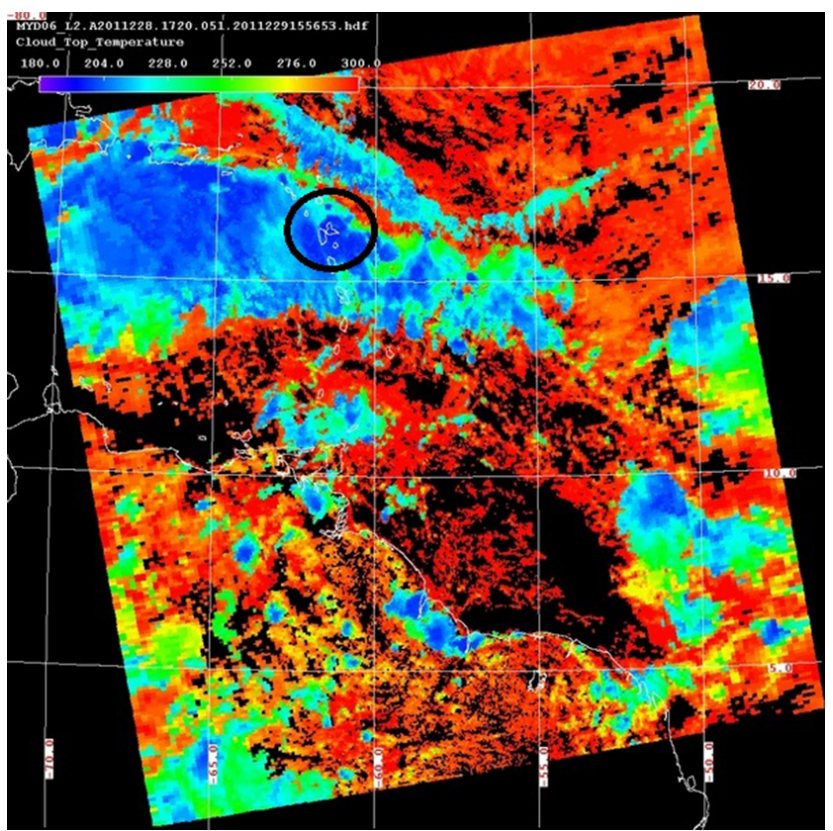

Figure A4. Cloud top temperature observed by the MODIS instrument. In the area of interest (black circle $61.64^{\circ} \mathrm{W} 16.19^{\circ} \mathrm{N}$ ) the cloud top temperature drops to $\approx 200 \mathrm{~K}$.

Comparing the data on the cloud effective radius, there is a discrepancy between MODIS and CARIBIC. The effective radius based on the MODIS observation was $22 \pm 6 \mu \mathrm{m}$; this agrees with CARIBIC data only for the CTH of 13.5 to $14.5 \mathrm{~km}$ (Table A1). On the other hand, the cloud top height according to MODIS was 120 to $105 \mathrm{hPa}$, i.e. 15 to $16 \mathrm{~km}$. Of course, the effective radius is a critical measure especially for ice clouds, and in Eq. (A1) we assume the ice crystal to be spherical, which is hardly ever the case. Measuring the cloud top temperature and pressure from a satellite should be more straightforward than calculating the effective radius. Moreover, there might be a difference in the effective radii when one observes from inside the cloud as compared to observing from above. Last but not least, the cloud properties may have changed in that $1 \mathrm{~h}$ time span between the MODIS observation and the CARIBIC measurements. We conclude that the existing discrepancy is noticeable, but not concerning, especially as the influence of CTH on the derived mixing ratios is rather small $( \pm 5 \%)$. 


\section{The Supplement related to this article is available online at doi:10.5194/acp-14-6621-2014-supplement.}

Acknowledgements. The authors wish to thank the World Wide Lightning Location Network (http://wwlln.net), a collaboration among over 50 universities and institutions, for providing the lightning location data used in this paper. The MODIS data used in this study were acquired as part of the NASA Earth-Sun System Division and archived and distributed by the MODIS Adaptive Processing System (MODAPS). The Atmospheric Chemistry group at NCAR is acknowledged for providing the Tropospheric Ultraviolet and Visible (TUV) Radiation Model online tool. We also thank the satellite group in Bremen for the $\mathrm{O}_{3}$ nadir images on the internet.

We thank Lufthansa Airlines and Lufthansa Technik, especially A. Waibel, T. Dauer, S. Dankert and D. Hartwig and of course the CARIBIC Team for their commitment and support. The DOAS system was built and operated by the Institut für Umweltphysik of the Universität Heidelberg. Rinus Scheele is acknowledged for helping with the trajectory calculations.

CARIBIC is financially supported by the German Ministry of Education and Science (IAGOS) and by the European Commission (IGAS). We thank Frankfurt Airport for financial support.

The service charges for this open access publication have been covered by the Max Planck Society.

Edited by: P. Chuang

\section{References}

Atkinson, R., Baulch, D. L., Cox, R. A., Crowley, J. N., Hampson, R. F., Hynes, R. G., Jenkin, M. E., Rossi, M. J., and Troe, J.: Evaluated kinetic and photochemical data for atmospheric chemistry: Volume $\mathrm{I}-$ gas phase reactions of $\mathrm{O}_{\mathrm{x}}, \mathrm{HO}_{\mathrm{x}}, \mathrm{NO}_{\mathrm{x}}$ and $\mathrm{SO}_{\mathrm{x}}$ species, Atmos. Chem. Phys., 4, 1461-1738, doi:10.5194/acp-41461-2004, 2004.

Atkinson, R., Baulch, D. L., Cox, R. A., Crowley, J. N., Hampson, R. F., Hynes, R. G., Jenkin, M. E., Rossi, M. J., Troe, J., and IUPAC Subcommittee: Evaluated kinetic and photochemical data for atmospheric chemistry: Volume II - gas phase reactions of organic species, Atmos. Chem. Phys., 6, 3625-4055, doi:10.5194/acp-6-3625-2006, 2006.

Apel, E. C., Olson, J. R., Crawford, J. H., Hornbrook, R. S., Hills, A. J., Cantrell, C. A., Emmons, L. K., Knapp, D. J., Hall, S., Mauldin III, R. L., Weinheimer, A. J., Fried, A., Blake, D. R., Crounse, J. D., Clair, J. M. St., Wennberg, P. O., Diskin, G. S., Fuelberg, H. E., Wisthaler, A., Mikoviny, T., Brune, W., and Riemer, D. D.: Impact of the deep convection of isoprene and other reactive trace species on radicals and ozone in the upper troposphere, Atmos. Chem. Phys., 12, 1135-1150, doi:10.5194/acp-12-1135-2012, 2012.

Baker, A. K., Slemr, F., and Brenninkmeijer, C. A. M.: Analysis of non-methane hydrocarbons in air samples collected aboard the CARIBIC passenger aircraft, Atmos. Meas. Tech., 3, 311-321, doi:10.5194/amt-3-311-2010, 2010.
Batenburg, A. M., Schuck, T. J., Baker, A. K., Zahn, A., Brenninkmeijer, C. A. M., and Röckmann, T.: The stable isotopic composition of molecular hydrogen in the tropopause region probed by the CARIBIC aircraft, Atmos. Chem. Phys., 12, 46334646, doi:10.5194/acp-12-4633-2012, 2012.

Baumgardner, D., Brenguier, J. L., Bucholtz, A., Coe, H., DeMott, P., Garrett, T. J., Gayet, J. F., Hermann, M., Heymsfield, A., Korolev, A., Krämer, M., Petzold, A., Strapp, W., Pilewskie, P., Taylor, J., Twohy, C., Wendisch, M., Bachalo, W., and Chuang, P.: Airborne instruments to measure atmospheric aerosol particles, clouds and radiation: A cook's tour of mature and emerging technology, Atmos. Res., 102, 10-29, doi:10.1016/j.atmosres.2011.06.021, 2011.

Beirle, S., Huntrieser, H., and Wagner, T.: Direct satellite observation of lightning-produced $\mathrm{NO}_{\mathrm{x}}$, Atmos. Chem. Phys., 10, 10965-10986, doi:10.5194/acp-10-10965-2010, 2010.

Bhetanabhotla, M. N., Crowell, B. A., Coucouvinos, A., Hill, R. D., and Rinker, R. G.: Simulation of trace species production by lightning and corona discharge in moist air, Atmos. Environ., 19, 1391-1397, 1985.

Bogumil, K., Orphal, J., Homann, T., Voigt, S., Spietz, P., Fleischmann, O. C., Vogel, A., Hartmann, M., Bovensmann, H., Frerik, J., and Burrows, J. P.: Measurements of Molecular Absorption Spectra with the SCIAMACHY Pre-Flight Model: Instrument Characterization and Reference Data for Atmospheric Remote-Sensing in the 230-2380 nm Region, J. Photoch. Photobio. A, 157, 167-184, doi:10.1016/s1010-6030(03)00062-5, 2003.

Brasseur, A. L., Ramaroson, R., Delannoy, A., Skamarock, W., and Barth, M.: Three-Dimensional Calculation of Photolysis Frequencies in the Presence of Clouds and Impact on Photochemistry, J. Atmos. Chem., 41, 211-237, doi:10.1023/A:1014952630482, 2002.

Brenninkmeijer, C. A. M., Crutzen, P., Boumard, F., Dauer, T., Dix, B., Ebinghaus, R., Filippi, D., Fischer, H., Franke, H., Frie?, U., Heintzenberg, J., Helleis, F., Hermann, M., Kock, H. H., Koeppel, C., Lelieveld, J., Leuenberger, M., Martinsson, B. G., Miemczyk, S., Moret, H. P., Nguyen, H. N., Nyfeler, P., Oram, D., O'Sullivan, D., Penkett, S., Platt, U., Pupek, M., Ramonet, M., Randa, B., Reichelt, M., Rhee, T. S., Rohwer, J., Rosenfeld, K., Scharffe, D., Schlager, H., Schumann, U., Slemr, F., Sprung, D., Stock, P., Thaler, R., Valentino, F., van Velthoven, P., Waibel, A., Wandel, A., Waschitschek, K., Wiedensohler, A., Xueref-Remy, I., Zahn, A., Zech, U., and Ziereis, H.: Civil Aircraft for the regular investigation of the atmosphere based on an instrumented container: The new CARIBIC system, Atmos. Chem. Phys., 7, 4953-4976, doi:10.5194/acp-7-4953-2007, 2007.

Bussemer, M.: Der Ring-Effekt: Ursachen und Einfluß auf die Messung stratosphärischer Spurenstoffe, diploma thesis, Universität Heidelberg, Germany, 1993.

Carter, W. P. L. and Atkinson, R.: Development and Evaluation of a Detailed Mechanism for the Atmospheric Reactions of Isoprene and $\mathrm{NO}_{\mathrm{x}}$, Int. J. Chem. Kinet., 28, 497-530, 1996.

Cecil, D. J., Buechler, D. E., and Blakeslee, R. J.: Gridded lightning climatology from TRMM-LIS and OTD: Dataset description, Atmos. Res., 135-136, 404-414, doi:10.1016/j.atmosres.2012.06.028, 2014.

Clémer, K., Van Roozendael, M., Fayt, C., Hendrick, F., Hermans, C., Pinardi, G., Spurr, R., Wang, P., and De Mazière, M.: Mul- 
tiple wavelength retrieval of tropospheric aerosol optical properties from MAXDOAS measurements in Beijing, Atmos. Meas. Tech., 3, 863-878, doi:10.5194/amt-3-863-2010, 2010.

Deutschmann, T., Beirle, S., Frieß, U., Grzegorski, M., Kern, C., Kritten, L., Platt, U., Prados-Román, C., Puksīte, J., Wagner, T., Werner, B., and Pfeilsticker, K.: The Monte Carlo atmospheric radiative transfer model McArtim: Introduction and validation of Jacobians and 3D features, J. Quant. Spectrosc. Ra., 112, 11191137, doi:10.1016/j.jqsrt.2010.12.009, 2011.

Dix, B.: Spectroscopic Measurements of Atmospheric Trace Gases on Long-Distance Flights, Ph.D. thesis, Universität Heidelberg, Germany, http://www.ub.uni-heidelberg.de/archiv/8118 (last access: 12 September 2013), 2007.

Dix, B., Brenninkmeijer, C. A. M., Frieß, U., Wagner, T., and Platt, U.: Airborne multi-axis DOAS measurements of atmospheric trace gases on CARIBIC long-distance flights, Atmos. Meas. Tech., 2, 639-652, doi:10.5194/amt-2-639-2009, 2009.

Ekman, A. M. L., Wang, C., Ström, J., and Krejci, R.: Explicit Simulation of Aerosol Physics in a Cloud-Resolving Model: Aerosol Transport and Processing in the Free Troposphere, J. Atmos. Sci., 63, 682-696, doi:10.1175/JAS3645.1, 2006.

Erle, F., Pfeilsticker, K., and Platt, U.: On the influence of tropospheric clouds on zenith-scattered-light measurements of stratospheric species, Geophys. Res. Lett., 22, 2725-2728, doi:10.1029/95g102789, 1995

Fried, A., Crawford, J., Olson, J., Walega, J., Potter, W., Wert, B., Jordan, C., Anderson, B., Shetter, R., Lefer, B., Blake, D., Blake, N., Meinardi, S., Heikes, B., O’Sullivan, D., Snow, J., Fuelberg, H., Kiley, C. M., Sandholm, S., Tan, D., Sachse, G., Singh, H., Faloona, I., Harward, C. N., and Carmichael, G. R.: Airborne tunable diode laser measurements of formaldehyde during TRACEP: Distributions and box model comparisons, J. Geophys. Res.Atmos., 108, 8798, doi:10.1029/2003JD003451, 2003.

Fried, A., Walega, J. G., Olson, J. R., Crawford, J. H., Chen, G., Weibring, P., Richter, D., Roller, C., Tittel, F. K., Heikes, B. G., Snow, J. A., Shen, H., O'Sullivan, D. W., Porter, M., Fuelberg, H., Halland, J., and Millet, D. B.: Formaldehyde over North America and the North Atlantic during the summer 2004 INTEX campaign: Methods, observed distributions, and measurementmodel comparisons, J. Geophys. Res.-Atmos., 113, D10302, doi:10.1029/2007JD009185, 2008a.

Fried, A., Olson, J. R., Walega, J. G., Crawford, J. H., Chen, G., Weibring, P., Richter, D., Roller, C., Tittel, F., Porter, M., Fuelberg, H., Halland, J., Bertram, T. H., Cohen, R. C., Pickering, K., Heikes, B. G., Snow, J. A., Shen, H., O'Sullivan, D. W., Brune, W. H., Ren, X., Blake, D. R., Blake, N., Sachse, G., Diskin, G. S., Podolske, J., Vay, S. A., Shetter, R. E., Hall, S. R., Anderson, B. E., Thornhill, L., Clarke, A. D., McNaughton, C. S., Singh, H. B., Avery, M. A., Huey, G., Kim, S., and Millet, D. B.: Role of convection in redistributing formaldehyde to the upper troposphere over North America and the North Atlantic during the summer 2004 INTEX campaign, J. Geophys. Res.-Atmos., 113, D17306, doi:10.1029/2007JD009760, 2008b.

Frieß, U., Monks, P. S., Remedios, J. J., Rozanov, A., Sinreich, R., Wagner, T., and Platt, U.: MAX-DOAS $\mathrm{O}_{4}$ measurements: A new technique to derive information on atmospheric aerosols: 2. Modelling studies, J. Geophys. Res., 111, D14203, doi:10.1029/2005JD006618, 2006.
Heue, K.-P.: Airborne Multi AXes DOAS instrument and measurements of two dimensional trace gas distribution, Ph.D. thesis, Universität Heidelberg, Germany, http://www.ub.uni-heidelberg. de/archiv/5990 (last access: 12 September 2013), 2005.

Heue, K.-P., Brenninkmeijer, C. A. M., Wagner, T., Mies, K., Dix, B., Frieß, U., Martinsson, B. G., Slemr, F., and van Velthoven, P. F. J.: Observations of the 2008 Kasatochi volcanic $\mathrm{SO}_{2}$ plume by CARIBIC aircraft DOAS and the GOME-2 satellite, Atmos. Chem. Phys., 10, 4699-4713, doi:10.5194/acp-10-46992010, 2010.

Heue, K.-P., Brenninkmeijer, C. A. M., Baker, A. K., RautheSchöch, A., Walter, D., Wagner, T., Hörmann, C., Sihler, H., Dix, B., Frieß, U., Platt, U., Martinsson, B. G., van Velthoven, P. F. J., Zahn, A., and Ebinghaus, R.: $\mathrm{SO}_{2}$ and BrO observation in the plume of the Eyjafjallajökull volcano 2010: CARIBIC and GOME-2 retrievals, Atmos. Chem. Phys., 11, 2973-2989, doi:10.5194/acp-11-2973-2011, 2011.

Huntrieser, H., Schlager, H., Lichtenstern, M., Roiger, A., Stock, P., Minikin, A., Höller, H., Schmidt, K., Betz, H.-D., Allen, G., Viciani, S., Ulanovsky, A., Ravegnani, F., and Brunner, D.: NOx production by lightning in Hector: first airborne measurements during SCOUT-O3/ACTIVE, Atmos. Chem. Phys., 9, 83778412, doi:10.5194/acp-9-8377-2009, 2009.

Jöckel, P., Kerkweg, A., Pozzer, A., Sander, R., Tost, H., Riede, H., Baumgaertner, A., Gromov, S., and Kern, B.: Development cycle 2 of the Modular Earth Submodel System (MESSy2), Geosci Model Dev., 3, 717-752, doi:10.5194/gmd-3-717-2010, 2010.

Jurkat, T., Voigt, C., Arnold, F., Schlager, H., Kleffmann, J., Aufmhoff, H., Schauble, D., Schaefer, M., and Schumann, U.: Measurements of $\mathrm{HONO}, \mathrm{NO}, \mathrm{NO}_{\mathrm{y}}$ and $\mathrm{SO}_{2}$ in aircraft exhaust plumes at cruise, Geophys. Res. Lett., 38, L10807, doi:10.1029/2011g1046884, 2011.

Klippel, T., Fischer, H., Bozem, H., Lawrence, M. G., Butler, T., Jöckel, P., Tost, H., Martinez, M., Harder, H., Regelin, E., Sander, R., Schiller, C. L., Stickler, A., and Lelieveld, J.: Distribution of hydrogen peroxide and formaldehyde over Central Europe during the HOOVER project, Atmos. Chem. Phys., 11, 4391-4410, doi:10.5194/acp-11-4391-2011, 2011.

Meller, R. and Moortgat, G. K.: Temperature dependence of the absorption cross sections of formaldehyde between 223 and $323 \mathrm{~K}$ in the wavelength range $225-375 \mathrm{~nm}$, J. Geophys. Res., 105, 7089-7101, 2000.

Mushtak, V. C., Williams, E. R., and Boccippio, D. J.: Latitudinal variations of cloud base height and lightning parameters in the tropics, Atmos. Res., 76, 222-230, doi:10.1016/j.atmosres.2004.11.010, 2005.

Nguyen, H. N., Gudmundsson, A., and Martinsson, B. G.: Design and calibration of a multi-channel aerosol sampler for tropopause region studies from the CARIBIC platform, Aerosol Sci. Tech., 40, 649-655, doi:10.1080/02786820600767807, 2006.

Pickering, K. E., Wang, Y., Tao, W.-K., Price, C., and Müller, J.F.: Vertical distributions of lightning NOx for use in regional and global chemical transport models, J. Geophys. Res.-Atmos., 103, 31203-31216, doi:10.1029/98JD02651, 1998.

Platt, U., Perner, D., Harris, G. W., Winer, A. M., and Pitts, J. N.: Observations of nitrous acid in an urban atmosphere by optical absorption, Nature, 285, 312-314, doi:10.1038/285312a0, 1980. 
Platt, U. and Stutz, J.: Differential Optical Absorption Spectroscopy, Principles and Applications, Springer, Berlin Heidelberg, 287-377, 2008.

Pommereau, J.-P., Garnier, A., Held, G., Gomes, A. M., Goutail, F., Durry, G., Borchi, F., Hauchecorne, A., Montoux, N., Cocquerez, P., Letrenne, G., Vial, F., Hertzog, A., Legras, B., Pisso, I., Pyle, J. A., Harris, N. R. P., Jones, R. L., Robinson, A. D., Hansford, G., Eden, L., Gardiner, T., Swann, N., Knudsen, B., Larsen, N., Nielsen, J. K., Christensen, T., Cairo, F., Fierli, F., Pirre, M., Marécal, V., Huret, N., Rivière, E. D., Coe, H., Grosvenor, D., Edvarsen, K., Di Donfrancesco, G., Ricaud, P., Berthelier, J.-J., Godefroy, M., Seran, E., Longo, K., and Freitas, S.: An overview of the HIBISCUS campaign, Atmos. Chem. Phys., 11, 23092339, doi:10.5194/acp-11-2309-2011, 2011.

Prather, M. J. and Jacob, D. J.: A persistent imbalance in HOx and NOx photochemistry of the upper troposphere driven by deep tropical convection, Geophys. Res. Lett., 24, 3189-3192, doi:10.1029/97GL03027, 1997.

Sander, R., Baumgaertner, A., Gromov, S., Harder, H., Jöckel, P., Kerkweg, A., Kubistin, D., Regelin, E., Riede, H., Sandu, A., Taraborrelli, D., Tost, H., and Xie, Z.-Q.: The atmospheric chemistry box model CAABA/MECCA-3.0, Geosci. Model Dev., 4, 373-380, doi:10.5194/gmd-4-373-2011, 2011.

Scheele, M. P., Siegmund, P. C., and van Velthoven, P. F. J.: Sensitivity of trajectories to data resolution and its dependence on the starting point: in or outside a tropopause fold, Meteorol. Appl., 3, 267-273, 1996.

Schuck, T. J., Brenninkmeijer, C. A. M., Slemr, F., Xueref-Remy, I., and Zahn, A.: Greenhouse gas analysis of air samples collected onboard the CARIBIC passenger aircraft, Atmos. Meas. Tech., 2, 449-464, doi:10.5194/amt-2-449-2009, 2009.

Schumann, U. and Huntrieser, H.: The global lightning-induced nitrogen oxides source, Atmos. Chem. Phys., 7, 3823-3907, doi:10.5194/acp-7-3823-2007, 2007.

Stickler, A., Fischer, H., Williams, J., de Reus, M., Sander, R., Lawrence, M. G., Crowley, J. N., and Lelieveld, J.: Influence of summertime deep convection on formaldehyde in the middle and upper troposphere over Europe, J. Geophys. Res., 111, D14308, doi:10.1029/2005JD007001, 2006.

Stohl, A., Haimberger, L., Scheele, M. P., and Wernli, H.: An intercomparison of results from three trajectory models, Meteorol. Appl., 8, 127-135, 2001.

Stutz, J., Kim, E. S., Platt, U., Bruno, P., Perrino, C., and Febo, A. UV-visible absorption cross sections of nitrous acid, J. Geophys. Res., 105, 14585-14592, doi:10.1029/2000JD900003, 2000.
Vandaele, A. C., Hermans, C., Simon, P., C., Van Roozendael, M., Guilmot, J. M., Carleer, M., and Colin, R.: Fourier transform measurement of $\mathrm{NO}_{2}$ absorption cross section in the visible range at room temperature, J. Atmos. Chem., 25, 289-305, 1996.

Vogel, L., Sihler, H., Lampel, J., Wagner, T., and Platt, U.: Retrieval interval mapping: a tool to visualize the impact of the spectral retrieval range on differential optical absorption spectroscopy evaluations, Atmos. Meas. Tech., 6, 275-299, doi:10.5194/amt6-275-2013, 2013.

Wagner, T., Dix, B., von Friedeburg, C., Frieß, U., Sanghavi, S., Sinreich, R., and Platt, U.: MAX-DOAS $\mathrm{O}_{4}$ measurements: A new technique to derive information on atmospheric aerosols - Principles and information content, J. Geophys. Res., 109, D22205, doi:10.1029/2004JD004904, 2004.

Wagner, T., Beirle, S., and Deutschmann, T.: Three-dimensional simulation of the Ring effect in observations of scattered sun light using Monte Carlo radiative transfer models, Atmos. Meas. Tech., 2, 113-124, doi:10.5194/amt-2-113-2009, 2009a.

Wagner, T., Deutschmann, T., and Platt, U.: Determination of aerosol properties from MAX-DOAS observations of the Ring effect, Atmos. Meas. Tech., 2, 495-512, doi:10.5194/amt-2-4952009, 2009b.

Walter, D., Heue, K.-P., Rauthe-Schöch, A., Brenninkmeijer, C. A. M., Lamsal, L. N., Krotkov, N. A., and Platt, U.: Flux calculation using CARIBIC DOAS aircraft measurements: $\mathrm{SO}_{2}$ emission of Norilsk, J. Geophys. Res., 117, D11305, doi:10.1029/2011JD017335, 2012.

Wang, Y., DeSilva, A. W., Goldenbaum, G. C., and Dickerson, R. R.: Nitric oxide production by simulated lightning: Dependence on current, energy, and pressure, J. Geophys. Res.-Atmos., 103, 19149-19159, doi:10.1029/98JD01356, 1998.

Wilmouth, D. M., Hanisco, T. F., Donahue, N. M., and Anderson, J. G.: Fourier transform ultraviolet spectroscopy of the A 2П3/2 X 2П3/2 transition of BrO, J. Phys. Chem. A, 103, 8935-8945, 1999.

Zhang, N., Zhou, X., Shepson, P. B., Gao, H., Alaghmand, M., and Stirm, B.: Aircraft measurement of HONO vertical profiles over a forested region, Geophys. Res. Lett., 36, L15820, doi:10.1029/2009GL038999, 2009.

Ziereis, H., Schlager, H., Schulte, P., van Velthoven, P. F. J., and Šlemr, F.: Distributions of $\mathrm{NO}, \mathrm{NO}_{\mathrm{x}}$, and $\mathrm{NO}_{\mathrm{y}}$ in the upper troposphere and lower stratosphere between $28^{\circ}$ and $61^{\circ} \mathrm{N}$ during POLINAT 2, J. Geophys. Res., 105, 3653-3664, 2000. 